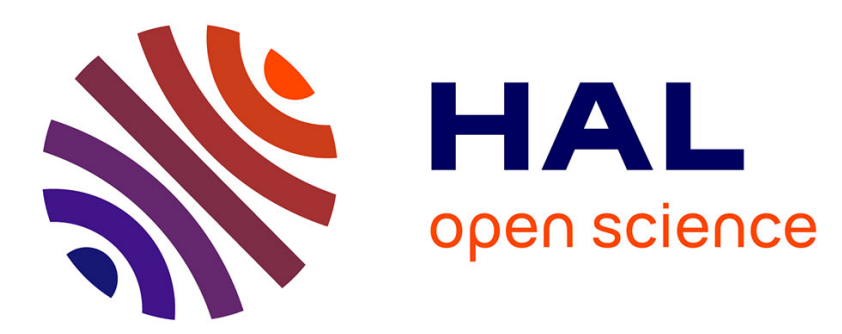

\title{
Supported oxides in the dehydration of isobutanol to butenes: relationships between acidic and catalytic properties
}

\author{
Z. Buniazet, C. Lorentz, A. Cabiac, S. Maury, S. Loridant
}

\section{- To cite this version:}

Z. Buniazet, C. Lorentz, A. Cabiac, S. Maury, S. Loridant. Supported oxides in the dehydration of isobutanol to butenes: relationships between acidic and catalytic properties. Molecular Catalysis, 2018, 451, pp.143-152. 10.1016/j.mcat.2017.12.007 . hal-01980795

\section{HAL Id: hal-01980795 \\ https://hal-ifp.archives-ouvertes.fr/hal-01980795}

Submitted on 14 Jan 2019

HAL is a multi-disciplinary open access archive for the deposit and dissemination of scientific research documents, whether they are published or not. The documents may come from teaching and research institutions in France or abroad, or from public or private research centers.
L'archive ouverte pluridisciplinaire HAL, est destinée au dépôt et à la diffusion de documents scientifiques de niveau recherche, publiés ou non, émanant des établissements d'enseignement et de recherche français ou étrangers, des laboratoires publics ou privés. 


\title{
Supported oxides in the dehydration of isobutanol to butenes: relationships between acidic and catalytic properties
}

\author{
Z. Buniazet ${ }^{1,2}$ C. Lorentz, ${ }^{1}$ A. Cabiac, ${ }^{2}$ S. Maury, ${ }^{2, *}$ S. Loridant ${ }^{1, *}$ \\ ${ }^{1}$ Institut de Recherches sur la Catalyse et l'Environnement de Lyon, IRCELYON, CNRS-Université \\ Claude Bernard Lyon 1, 2 av. Einstein, F-69626 Villeurbanne Cedex, France \\ ${ }^{2}$ IFP Energies nouvelles, Rond-point de l'échangeur de Solaize, BP 3, F-69360 Solaize, France
}

* Corresponding Authors: Ph. + 33 [0] 472445 334, Fax + 33 [0] 472445 399, E-mail stephane.loridant@ircelyon.univ-lyon1.fr 


\begin{abstract}
$\mathrm{H}_{4} \mathrm{SiW}_{12} \mathrm{O}_{40}$ heteropolyanions, $\mathrm{WO}_{3}, \mathrm{TiO}_{2}$ and $\mathrm{SnO}_{2}$ were supported over $\mathrm{SiO}_{2}$ at high loading by wet impregnation or grafting methods and evaluated in the dehydration of isobutanol to butenes. Their structural and textural properties were determined by different techniques such as XRD, TEM, IR, XPS and $\mathrm{N}_{2}$ liquid physisorption respectively. Most of the prepared compounds contained amorphous oxide clusters of few nanometers lying over $\mathrm{SiO}_{2}$ and were mesoporous. Their acidic properties (nature, density and strength) were investigated by pyridine and $\mathrm{CO}$ adsorption followed by FTIR. $\mathrm{H}_{4} \mathrm{SiW}_{12} \mathrm{O}_{40} / \mathrm{SiO}_{2}$ contained strong Brønsted acid sites while mostly moderate Lewis acid sites were present on $\mathrm{TiO}_{2} / \mathrm{SiO}_{2}$ and $\mathrm{SnO}_{2} / \mathrm{SiO}_{2}$. $\mathrm{WO}_{3} / \mathrm{SiO}_{2}$ had a mixed character with both moderate Brønsted and Lewis sites. The catalytic activity was related to the Brønsted acidity and the best selectivity to butenes close to $100 \%$ were obtained for the catalysts containing moderate and weak sites $\left(\mathrm{WO}_{3} / \mathrm{SiO}_{2}\right.$ and $\mathrm{TiO}_{2} / \mathrm{SiO}_{2}$ ). Except for $\mathrm{SnO}_{2} / \mathrm{SiO}_{2}$ catalysts, which were unstable and unselective to dehydration products, a significant selectivity to linear butenes (ca 30\%) was obtained. This isomerisation activity was mainly related to equilibrium between carbocations formed after $E_{1}$ elimination of water. Its slight increase for $\mathrm{H}_{4} \mathrm{SiW}_{12} \mathrm{O}_{40} / \mathrm{SiO}_{2}$ (and to a lesser extent $\mathrm{WO}_{3} / \mathrm{SiO}_{2}$ ) was attributed to strong Brønsted acid sites able to convert isobutene to linear butenes.
\end{abstract}

Keywords: oxide acidic catalysts; bio-alcohols; bio-olefins; dehydration; isomerisation; isobutanol; butenes. 


\section{Introduction}

Heterogeneous catalysis plays a crucial role in the upgrading of oxygenated biomass to produce fuels or chemicals by dehydration and hydrodeoxygenation reactions [1-6]. In particular, the dehydration of biosourced alcohols has gained much interest in the past two decades as a route to produce green olefins. The drop in bio-based polymers market is now emerging with an expected increasing growth rate. The most promising alcohol is ethanol which can be dehydrated to polymer grade ethylene. In 2014, the bio ethylene market still represented $0.2 \%$ of the global production estimated at 140 million tons per year. More recently, the dehydration of butanols has also received growing attention [7-9] as developments in biotechnology have led to produce different butanol isomers by lignocellulosic biomass fermentation with acceptable yields. Their transformation enables to produce butenes which can themselves serve directly as intermediates to chemicals, and namely bio-based polymer industry. The reaction of 2-butene with ethylene by metathesis reaction can be a route to propylene, a monomer for which a growing demand is observed. The catalysts efficient for the dehydration of n-butanol or sec-butanol to butenes are zeolites [8-11], silica-aluminas [12], tungstated zirconias [13] aluminas [12, 14-16] which are either of Brønsted or Lewis acidic type. It was shown that the dehydration rate of butanols in liquid phase increased with the number of Brønsted acid sites while no isomerization was observed in the conditions of the studies [17-19].

The dehydration of isobutanol has been more rarely studied [7,20-22] but this alcohol can actually be seen as a potential feedstock as it is produced by Gevo since 2016 (1.5 $\mathrm{Mgal} / \mathrm{yr}$ ) at an acceptable price. The formation of isobutyl carbonium ions in this reaction using H-ZSM-5 zeolites was evidenced by ${ }^{13} \mathrm{C}$ solid state NMR [23]. Kotsarenko et al. [24] firstly proposed a mechanism involving methyl-shift for the conjugated dehydration/isomerization of isobutanol to linear butenes occurring on different oxides and justifying the surprising selectivity to butenes on weak or medium strength acid sites. The proportion of linear butenes formed was however rather low. The increased Brønsted acidity of silica-aluminas compared to aluminas was shown to improve the selectivity to linear butenes [7]. Acidic catalysts such as $\mathrm{TiO}_{2}$ [25] or ferrierite [26] have also been patented for the specific reaction of conjugated dehydration-isomerization of isobutanol to linear butenes.

Chadwick et al. [8] studied the reverse reaction of n-butanol to isobutene over different zeolite catalysts (Theta-1, ZSM-23, ferrierite, ZSM-5, SAPO-11 and Y), their strong Brønsted acidity being the key to a high isomerization rate, but their low hydrothermal stability in the presence of water formed by dehydration leading to poor catalytic stability. 
Heteropolyacids such as $\mathrm{H}_{4} \mathrm{SiW}_{12} \mathrm{O}_{40}$ are also known to expose strong Brønsted acid sites which are efficient for isomerization of alkenes [27] and alkanes [28,29] as well as dehydration of alcohols [30-33]. Therefore, in order to evaluate catalytic properties of Brønsted acid catalysts in the dehydration of isobutanol to butenes, two different families of catalysts were explored in this work, $\mathrm{H}_{4} \mathrm{SiW}_{12} \mathrm{O}_{40}$ and $\mathrm{WO}_{3}$ supported on silica, the former being known to expose stronger Brønsted acid sites than the latter. For both solids, the proton lability results from the negative charge delocalization on $\mathrm{W}^{6+}[13,19,34,35]$.

As for Lewis acids, it is unclear from the literature if they can be active and selective in the conjugated dehydration/isomerization reaction of isobutanol. However, it should be emphasized that few authors have proposed that Lewis acid sites can be converted to Brønsted ones by reaction with water [36-40], which is present in high concentration in the case of dehydration reactions. These new sites could actually be active for the isomerization step in addition to the dehydration one. Therefore, in order to investigate the activity and selectivity of Lewis acids in the reaction studied, $\mathrm{TiO}_{2}$ and $\mathrm{SnO}_{2}$ acid catalysts which are known to be water tolerant $[38,39,41,42]$ were prepared. They were synthesized by methods aiming at maximizing their dispersion on a neutral silica support. $\mathrm{TiO}_{2} / \mathrm{SiO}_{2}$ is expected to have stronger Lewis acid sites than $\mathrm{SnO}_{2} / \mathrm{SiO}_{2}$ because of the stronger polarization effect of $\mathrm{Ti}^{4+}$ compared to $\mathrm{Sn}^{4+}$.

The textural and acidic properties of prepared solids were characterized by $\mathrm{N}_{2}$ physisorption and IR with two probe molecules (pyridine and $\mathrm{CO}$ ) respectively. Their structural properties were determined by XRD and TEM and in some cases completed with IR and XPS.

\section{Experimental part}

\subsection{Catalysts preparations}

$\mathrm{WO}_{3} / \mathrm{SiO}_{2}$ and $\mathrm{H}_{4} \mathrm{SiW}_{12} \mathrm{O}_{40} / \mathrm{SiO}_{2}$ compounds were synthesized by wet impregnation of high surface area $\mathrm{SiO}_{2}$ support (Grace, $550 \mathrm{~m}^{2} \cdot \mathrm{g}^{-1}, 3.3 \mathrm{OH} \cdot \mathrm{nm}^{-2}$, labelled $\mathrm{SiO}_{2}-\mathrm{G}$ in the following) with ammonium metatungstate $\left(\mathrm{NH}_{4}\right)_{6} \mathrm{H}_{2} \mathrm{~W}_{12} \mathrm{O}_{40} \cdot \mathrm{xH}_{2} \mathrm{O}$ (Strem Chemicals, 99,9\%) or silicotungstic acid $\mathrm{H}_{4} \mathrm{SiW}_{12} \mathrm{O}_{40} \cdot \mathrm{xH}_{2} \mathrm{O}$ (Sigma Aldrich, 99.9\%). The impregnation solutions were previously prepared by dissolving a given quantity of precursor in deionized water. They were deposited dropwise over sieved $\mathrm{SiO}_{2}-\mathrm{G}$ support $(\varnothing<80 \mu \mathrm{m})$ before mixing with spatula. The mixture was maturated for $6 \mathrm{~h}$ in wet atmosphere, then dried overnight at $110{ }^{\circ} \mathrm{C}$ and finally calcined under air flow $\left(60 \mathrm{~mL} \cdot \mathrm{min}^{-1} \cdot \mathrm{g}^{-1}\right)$. A calcination temperature of $450{ }^{\circ} \mathrm{C}$ was chosen for the $\mathrm{WO}_{3} / \mathrm{SiO}_{2}$ compounds from TGA/TDA measurements. It was high enough to 
decompose $\mathrm{NH}_{4}{ }^{+}$cations while limiting dehydroxylation of the $\mathrm{SiO}_{2}-\mathrm{G}$ support. For the $\mathrm{H}_{4} \mathrm{SiW}_{12} \mathrm{O}_{40} / \mathrm{SiO}_{2}$ supported heteropolyanions (HPAs), the calcination temperature was limited to $300{ }^{\circ} \mathrm{C}$ to avoid decomposition of Keggin units considering the literature [43].

Tin amide was preferred to other tin precursors because it does not contain chlorine and leads to high dispersion unlike tin acetate and dibutyltin dilaurate, for instance. In a glove box under $\mathrm{N}_{2}$ flow, a given quantity of bis[bis(trimethylsilyl)amino]tin(II) $\left[\left(\mathrm{Si}\left(\mathrm{CH}_{3}\right)_{3}\right)_{2} \mathrm{~N}_{2}\right] \mathrm{Sn}$ (Sigma Aldrich, 99.9\%) was dissolved in $5 \mathrm{~mL}$ of anhydrous tetrahydrofuran THF (Sigma Aldrich, $99.9 \%$ ) under magnetic stirring. $\mathrm{SiO}_{2}-\mathrm{G}$ support previously sieved below $80 \mu \mathrm{m}$ and treated at $200{ }^{\circ} \mathrm{C}$ for $2 \mathrm{~h}$ under vacuum was dissolved in $10 \mathrm{~mL}$ of anhydrous THF under magnetic stirring. The tin solution was then poured in the silica containing one. The mixture was kept under stirring for $6 \mathrm{~h}$ under $\mathrm{N}_{2}$ flow. The solid was recovered using a rotary evaporator, then dried at $110{ }^{\circ} \mathrm{C}$ overnight and finally calcined under air flow (60 mL.min $\left.{ }^{-1}\right)$ for $6 \mathrm{~h}$ at $550{ }^{\circ} \mathrm{C}$, temperature which was high enough to decompose the organic part of the tin precursor as determined by a TGA measurement.

The preparation method of $\mathrm{TiO}_{2} / \mathrm{SiO}_{2}$ compounds was previously reported [44]. Briefly, one molar equivalent of titanium(IV) isopropoxyde $\mathrm{Ti}(\mathrm{OiPr})_{4}$ (Sigma Aldrich, 99.999\%) and six molar equivalent of acetylacetone (acacH) were mixed under magnetic stirring in a glove box under $\mathrm{N}_{2}$ flow. A given quantity of $\mathrm{SiO}_{2}-\mathrm{G}$ support (Grace, $550 \mathrm{~m}^{2} \cdot \mathrm{g}^{-1}$ ) sieved below $80 \mu \mathrm{m}$ and previously desorbed for $2 \mathrm{~h}$ at $200{ }^{\circ} \mathrm{C}$ under vacuum was magnetically stirred in $10 \mathrm{~mL}$ of dry isopropanol. After pouring the titanium solution in the $\mathrm{SiO}_{2}$ containing one, the mixture was kept under stirring for $6 \mathrm{~h}$ until the colour changed from orange to milky yellow. The solid was recovered using a rotary evaporator, then dried overnight at $110^{\circ} \mathrm{C}$ and finally calcined at $425{ }^{\circ} \mathrm{C}$ for $6 \mathrm{~h}$ under air flow $\left(60 \mathrm{~mL} \cdot \mathrm{min}^{-1} \cdot \mathrm{g}^{-1}\right)$. The calcination temperature was chosen from a TGA measurement showing that the organic part of the solid was totally decomposed.

Different supported compounds were prepared with various loadings in order to maximize the loading for each supported oxide while keeping its amorphous character and hence maximize the number of acid sites. In the following, the sample labelling indicates the ICP weight percent of oxide phase supported over $\mathrm{SiO}_{2}-\mathrm{G}$ support.

\subsection{Catalysts characterization}

Structural characterization was obtained crossing X-rays diffraction (XRD) and Transmission Electronic Microscopy (TEM). XRD patterns were achieved between 5 and $80^{\circ}$ 
$(2 \Theta)$ on a Bruker D8 Advance A25 diffractometer equipped with a Ni filter $\left(\mathrm{Cu} \mathrm{K} \mathrm{K}_{\alpha}\right.$ radiation: $0.154184 \mathrm{~nm}$ ) and a one-dimensional multistrip detector (Lynxeye, 192 channels on $2.95^{\circ}$ ). The International Centre for Diffraction Data (ICDD) library was used for phase identification. TEM images were achieved with a JEOL 2010 microscope. The acceleration voltage was $200 \mathrm{kV}$ with $\mathrm{LaB}_{6}$ emission current and the point resolution was $0.19 \mathrm{~nm}$. Before measurements, a dispersion of catalyst in ethanol was deposited on standard holey carboncovered copper TEM grids. Additionally, ATR IR spectra of supported heteropolyacids $\mathrm{H}_{4} \mathrm{SiW}_{12} \mathrm{O}_{40} / \mathrm{SiO}_{2}$ were recorded with a Carry 630 FTIR spectrometer (Agilent Technologies) to check the integrity of Keggin units after drying and calcination.

Textural properties were obtained by nitrogen physisorption at $-196{ }^{\circ} \mathrm{C}$ with a Micromeritics ASAP 2020 instrument applying the BET and BJH methods to determine the specific surface areas $\left(\mathrm{S}_{\mathrm{BET}}\right)$, both the pore volumes $\left(\mathrm{V}_{\text {pores }}\right)$ and the pore diameters $\left(\mathrm{D}_{\text {pores }}\right)$ respectively.

Acidity properties were probed by adsorption of pyridine or $\mathrm{CO}$ using homemade IR cells working in the pressure range $10^{-5}-1$ bar. For all the measurements, self-supporting pellets $(15-30 \mathrm{mg})$ were pre-treated at $450{ }^{\circ} \mathrm{C}\left(300{ }^{\circ} \mathrm{C}\right.$ for HPAs) for $10 \mathrm{~h}$ under air flow which was exactly the activation treatment before catalytic testing. Spectra of CO adsorbed at $-196{ }^{\circ} \mathrm{C}$ were obtained by introducing small calibrated doses at increasing pressure and recorded with a Vertex 702 (Bruker) spectrometer equipped with DTGS detector. Pyridine adsorption experiments were performed with a homemade IR cell equipped with $\mathrm{KBr}$ windows under vacuum. The activated sample was exposed to a pressure of 4 mbar of pyridine at RT. Transmission IR spectra of samples desorbed under vacuum at increasing temperatures were then recorded at RT with a Vector 22 (Bruker) spectrometer equipped with DTGS detector. The spectral resolution was $2 \mathrm{~cm}^{-1}$. The bands at 1446 and $1547 \mathrm{~cm}^{-1}$ were chosen for quantification of Lewis and Brønsted acid sites densities using extinction coefficient values of 1.50 and $1.67 \mathrm{~cm} . \mu \mathrm{mol}^{-1}$, respectively [45-47].

Finally, TGA/DTA measurements of used catalysts were achieved under air flow (30 $\left.\mathrm{mL} \cdot \mathrm{min}^{-1}\right)$ from RT to $750{ }^{\circ} \mathrm{C}\left(5^{\circ} \mathrm{C} \cdot \mathrm{min}^{-1}\right)$ with a Mettler MX1 thermobalance to characterize the organic matter deposited over catalysts during reaction.

\subsection{Catalytic testing}

A first catalytic screening was carried out at $300{ }^{\circ} \mathrm{C}$ on a 4 parallel reactors experimental set-up equipped with stainless steel reactors of $10 \mathrm{~mm}$ internal diameter, 190 
$\mathrm{mm}$ length. The reactors were equipped with individual electrical heating systems. $1.5 \mathrm{~g}$ of 80-100 $\mu \mathrm{m}$ sieved catalyst were diluted with $3 \mathrm{~g}$ of $\mathrm{SiC}$ of the same granulometry before loading in reactor. The catalysts were pre-treated at $450{ }^{\circ} \mathrm{C}\left(300{ }^{\circ} \mathrm{C}\right.$ for $18.5 \%$ $\left.\mathrm{H}_{4} \mathrm{SiW}_{12} \mathrm{O}_{40} / \mathrm{SiO}_{2}-\mathrm{G}\right)$ for $2 \mathrm{~h}$ under synthetic air flow. Then, pure isobutanol was injected through lines heated at $150{ }^{\circ} \mathrm{C}$ in order to vaporize the reactant before it contacted the catalyst. No gas dilution was used, the unit configuration ensuring a good enough vaporization and the on-line analysis being well-optimized for high products concentrations. The totality of the gas effluent was analysed on-line on a gas chromatograph equipped with a GASPRO (length $30 \mathrm{~m}$, diameter $0.32 \mathrm{~mm}$ ) and PONA (length $50 \mathrm{~m}$, diameter $0.2 \mathrm{~mm}$, film thickness $0.5 \mu \mathrm{m}$ ) columns which enabled to quantify all the products formed and separated well the butenes isomers.

Low temperature tests $\left(\leq 200{ }^{\circ} \mathrm{C}\right)$ were achieved on a single reactor experimental setup previously described in details elsewhere [44] and summarized here: pure isobutanol (Aldrich, >99.5\%) was vaporized at $130{ }^{\circ} \mathrm{C}$ and diluted with a mixture of $\mathrm{N}_{2}$ and $\mathrm{CH}_{4} . \mathrm{CH}_{4}$ which was inert at the reaction temperatures was used as internal standard. The reaction feed was sent to a fixed bed Pyrex reactor (16 $\mathrm{mm}$ diameter, $35 \mathrm{~mm}$ length) at atmospheric pressure after catalyst pre-treatment at $450{ }^{\circ} \mathrm{C}\left(300{ }^{\circ} \mathrm{C}\right.$ for HPAs) for $2 \mathrm{~h}$ under synthetic air flow. Catalytic performances were obtained combining off line analysis (Shimadzu GC-2014, FID detector, Supelco column (30 m x $0.32 \mathrm{~mm} \times 0.25 \mu \mathrm{m})$ ) of trapped heavy products and unreacted isobutanol and on line analysis (Shimadzu GC-2014, FID detector, Agilent HPAL/KCL column (30 $\mathrm{m} \times 0,535 \mathrm{~mm} \times 15 \mu \mathrm{m})$ ) of $\mathrm{C} 1$ to $\mathrm{C} 5$ hydrocarbons. This protocol was applied for two selected catalysts: $39.7 \% \mathrm{WO}_{3} / \mathrm{SiO}_{2}-\mathrm{G}$ and $18.5 \% \mathrm{H}_{4} \mathrm{SiW}_{12} \mathrm{O}_{40} / \mathrm{SiO}_{2}-\mathrm{G}$.

In some cases, complementary analyses of the gas phase were obtained with a micro gas chromatograph-mass spectrometer ( $\mu \mathrm{GC}-\mathrm{MS})$ equipped with TCD detector and Agilent 5975 Mass detector coupled, GC analysis done on an alumina column (10 m x $3 \mathrm{~mm})$ ). The liquid phase was analysed by $\mathrm{GC} \times \mathrm{GC}-\mathrm{MS}$ equipment with a cryogenic modulator (Zoex corporation) on a Agilent 6890N GC coupled with an 5975B mass detector (scanning range on m/z: from 30 to 300, first apolar column: Phenomenex ZB-1MS (30 m x $0.25 \mathrm{~mm}$ x $1 \mathrm{um}$ ) and second polar column: Varian VF-17 (3 m x $0.1 \mathrm{~mm}$ x $0.2 \mathrm{um}$ ). 2D chromatograms were treated with GCimages software and the compound identification using the MS data was obtained with the NIST 2011 database.

All the GC measurements were accurate within 5\% and the formulas used to calculate the carbon yields, selectivity values and carbon balances were as follows: 


$$
\begin{aligned}
& \text { Conversion }(\%)=\frac{\text { moles }(\mathrm{iC} 4 \mathrm{H} 9 \mathrm{OH}) \text { in }- \text { moles }(\mathrm{iC} 4 \mathrm{H} 9 \mathrm{OH}) \text { out }}{\text { moles }(\mathrm{iC} 4 \mathrm{H} 9 \mathrm{OH}) \text { in }} \times 100 \\
& \mathrm{Y}_{\text {product }}(\%)=\mathrm{K} \times \frac{\text { moles of product }}{\text { moles }(\mathrm{iC} 4 \mathrm{H} 9 \mathrm{OH}) \text { in }} \times 100 \text { with } \mathrm{K}=\frac{\text { number of carbons in product }}{4} \\
& \mathrm{~S}_{\text {product }}(\%)=\frac{\text { Yproduct }}{\text { Conversion }} \times 100 \\
& \text { Carbon balance }(\%)=\sum \mathrm{YY}_{\text {product }}(\%)+100-\text { Conversion }(\%)
\end{aligned}
$$

The isomerization activity was related to the $S_{\text {LinBut }}$ parameter which corresponded to the proportion of linear butenes among the four butenes and was defined by:

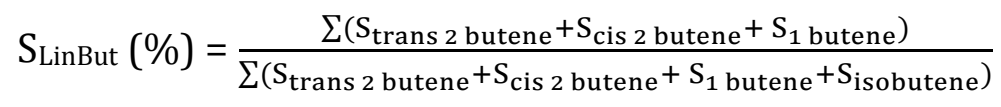

\section{Results}

\subsection{Characterization of the catalysts}

Figure 1 compares the XRD patterns of different supported compounds. No crystalline phase was observed except in the case of $39.7 \% \mathrm{WO}_{3} / \mathrm{SiO}_{2}-\mathrm{G}$ for which the main bands at 2324,34 and $42^{\circ}(2 \theta)$ were typical of $\alpha$ or $\gamma-\mathrm{WO}_{3}$ crystalline phase (ICDD 00-020-1324 and 00043-1035 respectively) [48]. At a loading of $15.9 \% \mathrm{WO}_{3}$, the small and broad bands at these angles revealed the presence of small nanocrystallites over silica support. For $\mathrm{H}_{4} \mathrm{SiW}_{12} \mathrm{O}_{40} / \mathrm{SiO}_{2}-\mathrm{G}$ compounds, the broad band at low angle $\left(7.8^{\circ}\right)$ could reveal the presence of crystallization water as observed in patterns of $\mathrm{H}_{4} \mathrm{SiW}_{12} \mathrm{O}_{40} \cdot \mathrm{xH}_{2} \mathrm{O}(\mathrm{x}>6)[49,50]$. As IR spectra evidenced preservation of $\mathrm{SiW}_{12} \mathrm{O}_{40}{ }^{4-}$ Keggin units after calcination (Fig. S1), the XRD band suggested that they are not isolated at the surface of $\mathrm{SiO}_{2}$ but would form amorphous clusters composed of few units. [51]. The comparison of TGA curves showed a slightly higher loss of physisorbed water $\left(\mathrm{T}<100{ }^{\circ} \mathrm{C}\right)$ for $18.5 \% \mathrm{H}_{4} \mathrm{SiW}_{12} \mathrm{O}_{40} / \mathrm{SiO}_{2}-\mathrm{G}$ compared to the sole support but very similar profile when heating from 100 to $500{ }^{\circ} \mathrm{C}$ (Figure S2). This second feature revealed that both the quantity of crystallization water was small and $\mathrm{H}_{4} \mathrm{SiW}_{12} \mathrm{O}_{40}$ was not decomposed (leading to a loss of 2 water molecules) during calcination in agreement with IR spectra. Note that deprotonation and decomposition of bulk $\mathrm{H}_{4} \mathrm{SiW}_{12} \mathrm{O}_{40}$ was reported at $300-350{ }^{\circ} \mathrm{C}$ and $530-535{ }^{\circ} \mathrm{C}$ respectively [50,52] while such processes occur at higher temperatures when $\mathrm{H}_{4} \mathrm{SiW}_{12} \mathrm{O}_{40}$ is supported [53]. The deviation of the two TGA curves from $540{ }^{\circ} \mathrm{C}$ suggested that $\mathrm{H}_{4} \mathrm{SiW}_{12} \mathrm{O}_{40}$ deprotonation occurred above this temperature. TEM images evidenced that amorphous clusters of few nanometers are well dispersed over $\mathrm{SiO}_{2}-\mathrm{G}$ for $26.0 \% \mathrm{SnO}_{2} / \mathrm{SiO}_{2}-\mathrm{G}, \quad 20.4 \% \mathrm{TiO}_{2} / \mathrm{SiO}_{2}-\mathrm{G} \quad$ and 
$18.5 \% \mathrm{H}_{4} \mathrm{SiW}_{12} \mathrm{O}_{40} / \mathrm{SiO}_{2}-\mathrm{G}$ compounds (Figure 2). XPS spectra of compounds prepared by grafting were achieved to go further in the characterization of such amorphous clusters. The $\mathrm{BE}$ values of the $\mathrm{O} 1 \mathrm{~s}, \mathrm{Si} 2 \mathrm{p}, \mathrm{Sn} 3 \mathrm{~d} 5 / 2$, Ti $2 \mathrm{p}$ peaks are gathered in Table $\mathrm{S} 1$ for $26.0 \% \mathrm{SnO}_{2} / \mathrm{SiO}_{2}-\mathrm{G}$ and $20.4 \% \mathrm{TiO}_{2} / \mathrm{SiO}_{2}-\mathrm{G}$ as well as $\mathrm{SiO}_{2}-\mathrm{G}$ sample. The $\mathrm{Sn} 3 \mathrm{~d} 5 / 2$ peak at $495.7 \mathrm{eV}$ indicated the presence of $\mathrm{Sn}^{4+}$ cations [54] in $26.0 \% \mathrm{SnO}_{2} / \mathrm{SiO}_{2}-\mathrm{G} . \mathrm{Sn}^{2+}$ cations are observed at $\mathrm{BE}$ values more than $0.5 \mathrm{eV}$ lower which suggested that $\mathrm{Sn}^{2+}$ cations contained in the tin amide precursor were oxidized to $\mathrm{Sn}^{4+}$ cations upon calcination at $450{ }^{\circ} \mathrm{C}$. The $\mathrm{Si} 2 \mathrm{p}$ $\mathrm{BE}$ value was slightly lower than the one of $\mathrm{SiO}_{2}-\mathrm{G}$ suggesting formation of $\mathrm{Sn}-\mathrm{O}-\mathrm{Si}$ bonds. The $\mathrm{O}$ 1s peak contained two individual Gaussian components located at 532.6 and $530.8 \mathrm{eV}$ which were attributed to $\mathrm{O}^{2-}$ anions present in $\mathrm{SiO}_{2}$ and $\mathrm{SnO}_{2}$ clusters respectively $[55,56]$. The Sn/Si XPS ratio was much higher than the corresponding ICP ratio ( 0.49 versus 0.14$)$ revealing a $\mathrm{Sn}$ enrichment at the outer surface of $\mathrm{SiO}_{2}$ particles. The $\mathrm{BE}$ value of the Ti 2p3/2 peak of $20.4 \% \mathrm{TiO}_{2} / \mathrm{SiO}_{2}-\mathrm{G}$ were close to the one of $\mathrm{TiO}_{2}-\mathrm{P} 25$ (Table S1) which indicated that they contained mainly $\mathrm{Ti}^{4+}$ cations with similar environment. The small blue-shift suggested the existence of Ti-O-Si bonds since $\mathrm{Si}$ has higher electronegativity than $\mathrm{Ti}[57,58]$. The $\mathrm{O} 1 \mathrm{~s}$ peak contained two individual Gaussian components located at 532.6 and $530.8 \mathrm{eV}$ attributed to $\mathrm{O}^{2-}$ anions present in $\mathrm{SiO}_{2}$ and $\mathrm{TiO}_{2}$ clusters respectively (Table $\mathrm{S} 1$ ). The Ti/Si XPS ratio was close to the corresponding ICP ratio (0.14 versus 0.19$)$ suggesting incorporation of $\mathrm{TiO}_{2}$ clusters inside the $\mathrm{SiO}_{2}$ pores.

The addition of oxides either by grafting or impregnation on silica support $\mathrm{SiO}_{2}-\mathrm{G}$ led to textural modifications evidenced by lower $\mathrm{S}_{\mathrm{BET}}$ and $\mathrm{V}_{\text {Pores}}$, as shown in Table 1. However, all the supported oxides were mesoporous as $\mathrm{SiO}_{2}-\mathrm{G}$ with pore diameters ranging from 4.7 to $5.5 \mathrm{~nm}$. The deposition mode was determined from the evolution of the pore diameter distribution with the oxide loading. For the $\mathrm{SnO}_{2} / \mathrm{SiO}_{2}-\mathrm{G}$ and $\mathrm{TiO}_{2} / \mathrm{SiO}_{2}-\mathrm{G}$ series (Figure $\mathrm{S} 3 \mathrm{a}$ and $b$, Table 1), the decrease in pore volume was associated with a decrease in pore size distribution which showed that the oxides added by a grafting method were well-deposited inside the pores. On the contrary, for the $\mathrm{WO}_{3} / \mathrm{SiO}_{2}-\mathrm{G}$ and $\mathrm{H}_{4} \mathrm{SiW}_{12} \mathrm{O}_{40} / \mathrm{SiO}_{2}-\mathrm{G}$ series (Figure S3c and d, Table 1), the decrease in pore volume was limited and the pore size distribution remained almost constant suggesting a deposit on the outer surface of $\mathrm{SiO}_{2}$ particles with possible plugging of some pore entrances.

$26.0 \% \mathrm{SnO}_{2} / \mathrm{SiO}_{2}-\mathrm{G}, 20.4 \% \mathrm{TiO}_{2} / \mathrm{SiO}_{2}-\mathrm{G}$ and $18.5 \% \mathrm{H}_{4} \mathrm{SiW}_{12} \mathrm{O}_{40} / \mathrm{SiO}_{2}-\mathrm{G}$ were selected for catalytic investigation because they combined high oxide loading and were amorphous as deduced from XRD. The surface density of the two formers were 3.0 atoms $\mathrm{SnO}_{2} \cdot \mathrm{nm}^{-2}$ and 
4.0 atoms $\mathrm{TiO}_{2} \cdot \mathrm{nm}^{-2}$ respectively (Table 1) while it was much lower for the latter $(0.10$ at $\mathrm{H}_{4} \mathrm{SiW}_{12} \mathrm{O}_{40} \cdot \mathrm{nm}^{-2}$ ) due to a much higher molecular weight. Furthermore, the two $\mathrm{WO}_{3} / \mathrm{SiO}_{2}-\mathrm{G}$ catalysts were kept for catalytic investigation to determine the influence of their crystallinity difference. Their surface densities were 1.0 and 3.1 at $\mathrm{WO}_{3} \cdot \mathrm{nm}^{-2}$ (Table 1).

\subsection{Acidity measurements}

Acidity measurements were obtained from FTIR spectra recorded after adsorbing pyridine and $\mathrm{CO}$ on the different catalysts. Figure 3 compares the spectra upon adsorption of pyridine at RT and evacuation at $150{ }^{\circ} \mathrm{C}$. The evolutions of the density of Lewis Acid Sites (LAS) and Brønsted Acid Sites (BAS) with the desorption temperature deduced from the raw spectra (Figures S4 and S5) are plotted in Figure 4a and 4b respectively. Both bands of pyridine coordinated to Lewis sites (labelled L in Figure 3) and bands of pyridinium cations (labelled B) formed by reaction of pyridine with BAS were observed for the different supported oxides while no band was observed for the bare $\mathrm{SiO}_{2}-\mathrm{G}$ support. The BAS density was quite low for $26.0 \% \mathrm{SnO}_{2} / \mathrm{SiO}_{2}-\mathrm{G}$ and $20.4 \% \mathrm{TiO}_{2} / \mathrm{SiO}_{2}-\mathrm{G}$ (Fig.4b) and much lower than the LAS one (Fig.4a). The highest BAS density was measured for $18.5 \% \mathrm{H}_{4} \mathrm{SiW}_{12} \mathrm{O}_{40} / \mathrm{SiO}_{2}-\mathrm{G}$ which also owned a low LAS density. Hence, the first supported oxides could be considered to have a Lewis acid character and the latter one a Brønsted acid one. $15.9 \% \mathrm{WO}_{3} / \mathrm{SiO}_{2}-\mathrm{G}$ and $39.7 \% \mathrm{WO}_{3} / \mathrm{SiO}_{2}-\mathrm{G}$ had an intermediate behaviour with lower densities of sites for the most loaded compound due to the presence of crystalline $\mathrm{WO}_{3}$. Furthermore, the temperature dependence of BAS density indicated that their strength followed the sequence: $18.5 \% \mathrm{H}_{4} \mathrm{SiW}_{12} \mathrm{O}_{40} / \mathrm{SiO}_{2}-\mathrm{G}>15.9 \% \mathrm{WO}_{3} / \mathrm{SiO}_{2}-\mathrm{G}>39.7 \% \mathrm{WO}_{3} / \mathrm{SiO}_{2}-\mathrm{G}>20.4 \% \mathrm{TiO}_{2} / \mathrm{SiO}_{2}-\mathrm{G}$ $>26.0 \% \mathrm{SnO}_{2} / \mathrm{SiO}_{2}-\mathrm{G}$. In particular, $18.5 \% \mathrm{H}_{4} \mathrm{SiW}_{12} \mathrm{O}_{40} / \mathrm{SiO}_{2}-\mathrm{G}$ and $15.9 \% \mathrm{WO}_{3} / \mathrm{SiO}_{2}-\mathrm{G}$ for which pyridine was still adsorbed after thermal treatment at $350{ }^{\circ} \mathrm{C}$ owned the strongest BAS. It is worth noting that the acidity strength of supported HPAs depends on their interaction with the support and that the weak interaction in the case of $\mathrm{SiO}_{2}$ support allows to keep strong acidity of Keggin units [59].

The LAS strength was similar for the different compounds as suggested by the temperature dependences of their densities and more accurately measured by the position of the 8a mode of LAS which only varied from 1608 to $1616 \mathrm{~cm}^{-1}$ (Fig. 3). Such positions corresponded to a shift of $25-33 \mathrm{~cm}^{-1}$ compared to the position of liquid pyridine $\left(1583 \mathrm{~cm}^{-1}\right)$ typical of moderate LAS [60,61]. Interestingly, the shift of $33 \mathrm{~cm}^{-1}$ observed for $26.0 \% \mathrm{SnO}_{2} / \mathrm{SiO}_{2}-\mathrm{G}$ was quite similar to bulk $\mathrm{SnO}_{2}$ [62] $\left(32 \mathrm{~cm}^{-1}\right)$ clearly showing that $\mathrm{Sn}^{2+}$ were oxidized to $\mathrm{Sn}^{4+}$ cations upon calcination in agreement with XPS data. Finally, the LAS 
strength appeared as slightly lower for $20.4 \% \mathrm{TiO}_{2} / \mathrm{SiO}_{2}-\mathrm{G}$ compared to the other compounds using pyridine as acidity probe.

FTIR spectra of different compounds recorded upon adsorption of increasing $\mathrm{CO}$ doses at $77 \mathrm{~K}$ are provided in Figure S6 and S7. Before adsorption, bands typical of $v(\mathrm{O}-\mathrm{H})$ vibrations of terminal and bridging hydroxyl groups were observed at 3740 and $3718 \mathrm{~cm}^{-1}$ respectively $[63,64]$. Interaction of $\mathrm{CO}$ with these groups led to a similar shift to lower wavenumbers for the five compounds (Table S2) suggesting that mostly silanol groups of the $\mathrm{SiO}_{2}$ support interacted with $\mathrm{CO}$. The corresponding $v(\mathrm{C} \equiv \mathrm{O})$ stretching vibration was observed at $2156 \mathrm{~cm}^{-1}$ (H-bonded) in addition to the $v(\mathrm{C} \equiv \mathrm{O})$ band of physisorbed $\mathrm{CO}$ (2136 $\left.\mathrm{cm}^{-1}\right)$. The $v(\mathrm{C} \equiv \mathrm{O})$ stretching vibrations of LAS were observed at higher wavenumbers. FTIR spectra recorded upon adsorption of small quantities of $\mathrm{CO}$ allowed observation of such bands which were hidden at higher coverage by the two above-mentioned bands. They are compared in Figure 5 for the different catalysts. It confirmed that $26.0 \% \mathrm{SnO}_{2} / \mathrm{SiO}_{2}-\mathrm{G}$ and $20.4 \% \mathrm{TiO}_{2} / \mathrm{SiO}_{2}-\mathrm{G}$ contained moderate LAS. The band shift from 2188 to $2179 \mathrm{~cm}^{-1}$ for $20.4 \% \mathrm{TiO}_{2} / \mathrm{SiO}_{2}-\mathrm{G}$ was attributed to the presence of $\beta$ ' and $\beta$ " five-coordinated $\mathrm{Ti}^{4+}$ sites respectively [44]. Adsorption of $\mathrm{CO}$ on defective bulk $\mathrm{SnO}_{2}$ led to observation of a $v(\mathrm{C} \equiv \mathrm{O})$ band near $2200 \mathrm{~cm}^{-1}$ [65] which corresponded to stronger sites than in the present study for supported $\mathrm{SnO}_{2}$. In another study on high surface area $\mathrm{SnO}_{2}[66]$, the $v(\mathrm{C} \equiv \mathrm{O})$ band of $\mathrm{Sn}^{4+}$ cations strongly bonding CO were observed at 2210-2196 $\mathrm{cm}^{-1}$ and at lower wavenumbers (2183-2177 $\mathrm{cm}^{-1}$ ) for $\mathrm{Sn}^{4+}$ less acidic cations. The latter sites seem to correspond to the ones observed in the present study. Anyway, it confirmed a new time the presence of $\mathrm{Sn}^{4+}$ cations in $26.0 \% \mathrm{SnO}_{2} / \mathrm{SiO}_{2}-\mathrm{G}$. $\mathrm{WO}_{3} / \mathrm{SiO}_{2}-\mathrm{G}$ catalysts contained weak, moderate and strong LAS leading to $v(\mathrm{C} \equiv \mathrm{O})$ band at 2170,2181 and $2212 \mathrm{~cm}^{-1}$ respectively. The strongest sites were assigned to $\mathrm{W}^{6+}$ coordinatively unsaturated sites present in molecular polytungstates [67]. The moderate sites present in much higher proportion for $39.7 \% \mathrm{WO}_{3} / \mathrm{SiO}_{2}-\mathrm{G}$ could correspond to $\mathrm{W}^{6+}$ penta-coordinated cations present at the surface of crystalline $\mathrm{WO}_{3}$. Finally, weak and moderate LAS should be present in $18.5 \% \mathrm{H}_{4} \mathrm{SiW}_{12} \mathrm{O}_{40} / \mathrm{SiO}_{2}-\mathrm{G}$ (Table S2) even though they were hardly distinguished because of intense $\mathrm{H}$-bonded $v(\mathrm{C} \equiv \mathrm{O})$ band at $2156 \mathrm{~cm}^{-1}$. Such sites could be generated during the calcination step $\left(300{ }^{\circ} \mathrm{C}\right.$ at atmospheric pressure) but not consecutively during the pre-treatment achieved before probe molecule adsorption since the conditions were identical (in particular, no vacuum). In that mind, no surface Lewis acid site was observed for unsupported and $\mathrm{SiO}_{2}$-supported $\mathrm{H}_{4} \mathrm{SiW}_{12} \mathrm{O}_{40}$, regardless of the loading amount after calcination at $250{ }^{\circ} \mathrm{C}$ in air [68]. 
Overall, $\mathrm{CO}$ adsorption appeared as much more sensitive than pyridine to distinguish the LAS strengths. Strong LAS were evidenced only for $\mathrm{WO}_{3} / \mathrm{SiO}_{2}-\mathrm{G}$ catalysts while the other supported oxides contained moderate LAS.

\subsection{Catalytic results}

\subsubsection{Screening at $300{ }^{\circ} \mathrm{C}$}

A catalytic screening was achieved at $300{ }^{\circ} \mathrm{C}$ and 1/WHSV $0.33 \mathrm{~h}$ using a feed containing $100 \%$ isobutanol. Catalytic data were recorded each $4 \mathrm{~h}$ for $20 \mathrm{~h}$ and the ones obtained after $4 \mathrm{~h}$ and $20 \mathrm{~h}$ on stream are gathered in Table 2. The data evolutions between 4 and $20 \mathrm{~h}$ were monotonous as illustrated by the Figure $\mathrm{S} 8.18 .5 \% \mathrm{H}_{4} \mathrm{SiW}_{12} \mathrm{O}_{40} / \mathrm{SiO}_{2}-\mathrm{G}$ was excluded because of too high activity in these conditions (complete conversion even after $20 \mathrm{~h}$ hindering accurate comparison of selectivity). $\mathrm{SiO}_{2}-\mathrm{G}$ was slightly active ( $3.5 \%$ conversion) producing mainly dehydration products ie butenes (ca 90\%) and in minority C5+ products (9\%). A significant proportion of linear butenes was obtained $\left(\mathrm{S}_{\mathrm{LinBut}} 30 \%\right)$.

Among the two Lewis type catalysts, $26.0 \% \mathrm{SnO}_{2} / \mathrm{SiO}_{2}-\mathrm{G}$ was barely more active and presented a low selectivity to butenes (only 15-16\%). The main product was isobutyraldehyde corresponding to dehydrogenating activity which increased over time on stream. The XRD pattern achieved on the used catalyst contained peaks due to tetragonal Sn phase in addition to hexagonal SiC phase used as diluent (Figure S9). It revealed that amorphous $\mathrm{SnO}_{2}$ clusters were reduced to Sn crystalline particles under isobutanol vapour at $300{ }^{\circ} \mathrm{C}$ leading to dehydrogenating activity. High conversion (89.3\%) and very high selectivity to butenes (97.4\%) was obtained using $20.4 \% \mathrm{TiO}_{2} / \mathrm{SiO}_{2}-\mathrm{G}$ after $4 \mathrm{~h}$. Such feature was in agreement with data obtained in the same conditions of temperature and contact time but with a diluted feed $\mathrm{iC}_{4} \mathrm{OH} / \mathrm{inert}$ : $35 / 65$ [44]. The isomerisation activity was slightly higher than the $\mathrm{SiO}_{2}-\mathrm{G}$ one $\left(\mathrm{S}_{\text {LinBut }} 33 \%\right.$ instead of $\left.30 \%\right)$ and close to values reported in the literature for mixed oxides [24]. It is worth noting that a value of $33 \%$ was also measured at $300{ }^{\circ} \mathrm{C}$ for feed composition $\mathrm{iC}_{4} \mathrm{OH} /$ inert 35/65 and 1/WHSV $0.30 \mathrm{~h}$ [44]. After $20 \mathrm{~h}$ on stream, the conversion was lowered to $64.8 \%$ which corresponded to a faster deactivation than for a diluted feed [44]. This result was ascribed to the high reactant concentration favouring consecutive reactions and leading to formation of $\mathrm{C} 5+$ products (selectivity of $5.1 \%$ after $20 \mathrm{~h}$ ) and consecutively to coke. 
The two $\mathrm{WO}_{3} / \mathrm{SiO}_{2}-\mathrm{G}$ catalysts which contained moderated $\mathrm{BAS}$ in addition of strong LAS were the most active with complete conversion after $4 \mathrm{~h}$ on stream. After $20 \mathrm{~h}$, $39.7 \% \mathrm{WO}_{3} / \mathrm{SiO}_{2}-\mathrm{G}$ was more active than $15.9 \% \mathrm{WO}_{3} / \mathrm{SiO}_{2}-\mathrm{G}$ (Table 2) suggesting that its lower BAS density (Figure 4b) due to the presence of crystalline $\mathrm{WO}_{3}$ (Figure 1) was not redhibitory but could lead to lower deactivation by coking. The two catalysts were initially less selective to butenes than $20.4 \% \mathrm{TiO}_{2} / \mathrm{SiO}_{2}-\mathrm{G}$ because of $\mathrm{C} 5+$ products formation but became very selective after $20 \mathrm{~h}$ ( $>98 \%$ of butenes). The $\mathrm{S}_{\mathrm{LinBut}}$ values measured for the two catalysts were similar, almost constant and the highest among the screened catalysts indicating both that the linear butenes were mainly formed from thermodynamic equilibrium between the four carbocations [44] and that another less favourable isobutene isomerisation route was activated.

\subsubsection{Evaluation of catalytic performances at lower temperature}

In order to better discriminate the catalysts (conversion lower than $100 \%$ ), they have also been tested at $200{ }^{\circ} \mathrm{C}$ with a diluted feed ( $\mathrm{iC}_{4} \mathrm{OH} /$ inert 35/65, 1/WHSV $0.35 \mathrm{~h}$ ). The two Lewis type catalysts $\left(26.0 \% \mathrm{SnO}_{2} / \mathrm{SiO}_{2}-\mathrm{G}\right.$ and $\left.20.4 \% \mathrm{TiO}_{2} / \mathrm{SiO}_{2}-\mathrm{G}\right)$ were almost inactive in these conditions. Figure 6 displays the evolution of catalytic performances measured with time on stream for $39.7 \% \mathrm{WO}_{3} / \mathrm{SiO}_{2}-\mathrm{G}$ : the initially high conversion $(69.0 \%)$ was damped quickly after $22 \mathrm{~h}(37.6 \%)$. In parallel, the selectivity to butenes and the carbon balance increased to reach ca $100 \%$. It suggested that butenes did not desorb and/or consecutively reacted during the first hours on stream to form coke precursors leading to deactivation. The $\mathrm{S}_{\mathrm{LinBut}}$ value was almost constant during the catalytic testing (25.1-26.1\%) and lower than the value measured at $300{ }^{\circ} \mathrm{C}$ which was attributed to the temperature dependence of the thermodynamic equilibria between the different butyl carbenium cations leading to butenes $[7,25,69,70]$.

As a comparison, $18.5 \% \mathrm{H}_{4} \mathrm{SiW}_{12} \mathrm{O}_{40} / \mathrm{SiO}_{2}-\mathrm{G}$ which own strong $\mathrm{BAS}$ and moderated LAS led to a conversion of $67.4 \%$ and $\mathrm{S}_{\text {LinBut }}$ value of $29.3 \%$ after $24 \mathrm{~h}$ at $200{ }^{\circ} \mathrm{C}$. As the initial conversion of $100 \%$ did not allow determining deactivation rate and accurate comparison of selectivity, the evolution of its catalytic performances with time on stream was investigated in details at $175{ }^{\circ} \mathrm{C}$ (Figure 7). The initial conversion was higher than for $39.7 \% \mathrm{WO}_{3} / \mathrm{SiO}_{2}-\mathrm{G}$ catalyst at $200{ }^{\circ} \mathrm{C}$ clearly showing this catalyst was the most active among all the catalysts of the present study. Again, an important deactivation was observed (from 85.9 to $56.6 \%$ during the first nine hours) associated with an increase in the carbon 
balance (from 80 to ca 100\%). This increase was mainly explained by the raise of the selectivity to isobutene which seems to indicate that isobutene was initially not desorbed and/or transformed to coke precursors and heavy products by consecutive oligomerisation and cyclisation reactions. Hence, the $S_{\text {LinBut }}$ value was not considered for short times on stream. Deactivation was much slower between 9 and $24 \mathrm{~h}$. The $\mathrm{S}_{\text {LinBut }}$ value was then slightly lower than at $200{ }^{\circ} \mathrm{C}(27.1 \%$ versus $29.3 \%)$ confirming the effect of temperature on this parameter $[7,25,69,70]$.

Furthermore, the selectivity to butenes remained much lower $(<80 \%)$ compared to supported $\mathrm{WO}_{3}$ and $\mathrm{TiO}_{2}$ (ca 100\%). As unknown products were detected by the on-line analysis of the gas phase and the off-line analysis of condensates, complementary analysis

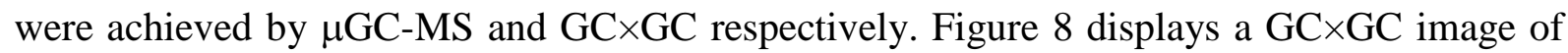
one condensate obtained after $24 \mathrm{~h}$ of $18.5 \% \mathrm{H}_{4} \mathrm{SiW}_{12} \mathrm{O}_{40} / \mathrm{SiO}_{2}-\mathrm{G}$ testing. It revealed the presence of unsaturated $\mathrm{C} 5$ to $\mathrm{C} 8$ products and one $\mathrm{C} 8$ ether soluble in water/ethanol mixture. Such molecules were formed by oligomerisation of either butenes or butenes with isobutanol casually followed by successive cracking or aromatization. It is worth noting that a low temperature favours formation of ethers by dehydration of alcohols using HPAs [32,33,71] but such formation from isobutanol is unfavourable because of stable intermediate alkoxide [72]. A selectivity to $\mathrm{C} 5+$ products of ca $10 \%$ was estimated from calibration of 2 methyl-2pentene. The $\mu \mathrm{GC}-\mathrm{MS}$ analysis of the gas phase after $24 \mathrm{~h}$ of $18.5 \% \mathrm{H}_{4} \mathrm{SiW}_{12} \mathrm{O}_{40} / \mathrm{SiO}_{2}-\mathrm{G}$ testing (Figure S10) evidenced formation of propane and/or propene (RT $0.36 \mathrm{~min}$ ), isobutane (RT $0.40 \mathrm{~min}$ ) and n-butane (RT $0.42 \mathrm{~min}$ ) in addition to butenes. Considering different formation mechanisms of by-products identified by $\mathrm{GC} \times \mathrm{GC}$ and $\mu \mathrm{GC}-\mathrm{MS}$ (Figure S11), it was proposed that isobutane was formed by hydrogen transfer. Indeed, aromatization of olefins leads to $\mathrm{H}_{2}$ formation that can react with olefins leading to alkanes. As no aromatic compound was detected by $\mathrm{GC} \times \mathrm{GC}$, they might remain adsorbed on the surface leading to coke deposit. TGA/TDA measurements achieved on $18.5 \% \mathrm{H}_{4} \mathrm{SiW}_{12} \mathrm{O}_{40} / \mathrm{SiO}_{2}-\mathrm{G}$ (Figure S12) revealed the presence of an important quantity of coke (ca $10.7 \mathrm{wt} \%$ ) which explained both the poor carbon balances for the first hours of testing and fast deactivation. The two weight loss (5.0 and 5.7\%) associated to exothermic peaks at 269 and $450{ }^{\circ} \mathrm{C}$ were attributed to organic compounds adsorbed on the solid [73] and aromatic coke (hard coke) [59,74,75] respectively.

\section{Discussion}


The following activity sequence was deduced from the catalytic measurements: $18.5 \% \mathrm{H}_{4} \mathrm{SiW}_{12} \mathrm{O}_{40} / \mathrm{SiO}_{2}-\mathrm{G}>39.7 \% \mathrm{WO}_{3} / \mathrm{SiO}_{2}-\mathrm{G}>20.4 \% \mathrm{TiO}_{2} / \mathrm{SiO}_{2}-\mathrm{G}>26.0 \% \mathrm{SnO}_{2} / \mathrm{SiO}_{2}-\mathrm{G}$ which correlates with the ranking of the BAS density and strength (Figure 7b). It confirms that Brønsted sites are active in the isobutanol dehydration via E1 elimination mechanism [24]. The Brønsted acidity of $\mathrm{H}_{4} \mathrm{SiW}_{12} \mathrm{O}_{40} / \mathrm{SiO}_{2}-\mathrm{G}$ and $\mathrm{WO}_{3} / \mathrm{SiO}_{2}-\mathrm{G}$ catalysts arise from electron delocalization on $\mathrm{W}^{6+}$ cations and is related to their reducibility $[13,19,34,35]$. The weak Brønsted acidity of $\mathrm{TiO}_{2} / \mathrm{SiO}_{2}-\mathrm{G}$ catalysts was associated to Ti-O-Si bonds generating a charge unbalance between tetrahedral $\mathrm{Si}^{4+}$ and octahedral or pentahedral $\mathrm{Ti}^{4+}$ cations [44]. No correlation was found between the activity sequence and neither the LAS density nor their strength suggesting their activity was much smaller or null. For instance, $20.4 \% \mathrm{TiO}_{2} / \mathrm{SiO}_{2}-\mathrm{G}$ and $26.0 \% \mathrm{SnO}_{2} / \mathrm{SiO}_{2}-\mathrm{G}$ which presented high densities of moderate LAS were the two less active solids. All the catalysts suffered from deactivation using pure isobutanol feed and the two most active ones $\left(18.5 \% \mathrm{H}_{4} \mathrm{SiW}_{12} \mathrm{O}_{40} / \mathrm{SiO}_{2}-\mathrm{G}\right.$ and $\left.39.7 \% \mathrm{WO}_{3} / \mathrm{SiO}_{2}-\mathrm{G}\right)$ also quickly deactivated using diluted feed contrary to $20.4 \% \mathrm{TiO}_{2} / \mathrm{SiO}_{2}-\mathrm{G}$ [44]. It underlined the need to tailor the BAS strength to limit deactivation.

Selectivity values to butenes close to $100 \%$ were obtained for $39.7 \% \mathrm{WO}_{3} / \mathrm{SiO}_{2}-\mathrm{G}$ and $20.4 \% \mathrm{TiO}_{2} / \mathrm{SiO}_{2}-\mathrm{G}$ while it was limited to $80 \%$ for $18.5 \% \mathrm{H}_{4} \mathrm{SiW}_{12} \mathrm{O}_{40} / \mathrm{SiO}_{2}-\mathrm{G}$. It showed that weak and moderate BAS are able to dehydrate isobutanol and that strong BAS activate other routes such as cracking and oligomerisation reactions. We identified secondary products such as unsaturated $\mathrm{C} 8$ molecules formed by oligomerisation of $\mathrm{C} 4$ olefins and light alkanes (mostly isobutane) revealing hydrogen transfer reactions with $18.5 \% \mathrm{H}_{4} \mathrm{SiW}_{12} \mathrm{O}_{40} / \mathrm{SiO}_{2}-\mathrm{G}$ catalyst. $26.0 \% \mathrm{SnO}_{2} / \mathrm{SiO}_{2}-\mathrm{G}$ was unselective to dehydration products because of very small BAS density (Figure 7b) and/or reduction of $\mathrm{SnO}_{2}$ to metallic $\mathrm{Sn}$ in reaction conditions. The dehydrogenating activity of $26.0 \% \mathrm{SnO}_{2} / \mathrm{SiO}_{2}-\mathrm{G}$ could arise from tin reduced oxide species since $\mathrm{Sn}$ species with oxygen vacancies adjacent to the Lewis acid sites and $\mathrm{Si}^{4+}-\mathrm{O}-\mathrm{Sn}^{2+}$ were proposed to be the active sites in the dehydrogenation of propane over Sn-HMS [76] and silica-supported tin oxide [77] catalysts respectively.

In spite of very different BAS strengths, the $S_{\text {LinBut }}$ value did not vary much from one catalyst to the other and compared to $\mathrm{SiO}_{2}-\mathrm{G}$ at $300^{\circ} \mathrm{C}$ (Table 2). Furthermore, similar values are reported in the literature for different mixed oxides [24]. Note that $\gamma-\mathrm{Al}_{2} \mathrm{O}_{3}$ appeared as an exception with selectivity to isobutene higher than $90 \%$ at $300{ }^{\circ} \mathrm{C}$ [7,24]. For $\mathrm{TiO}_{2} / \mathrm{SiO}_{2}-\mathrm{G}$ catalysts, we have previously shown that the $S_{\text {LinBut }}$ value did not vary with the contact time and increased slightly raising the temperature from 250 to $300{ }^{\circ} \mathrm{C}$ [44]. In the present study, a 
temperature dependence was also disclosed for $\mathrm{WO}_{3} / \mathrm{SiO}_{2}-\mathrm{G}$ and $\mathrm{H}_{4} \mathrm{SiW}_{12} \mathrm{O}_{40} / \mathrm{SiO}_{2}-\mathrm{G}$ catalysts. Hence, the linear butenes appeared as mainly formed from thermodynamic equilibrium between the four carbocations (Figure 9) after E1 elimination of water involving Brønsted sites [24,69]. The temperature dependence of this equilibrium leads to the increase in the $\mathrm{S}_{\text {LinBut }}$ value with temperature. Kotsarenko et al. underlined that the high adsorption capacity and reactivity of isobutanol lead to a high concentration of isobutylcarbonium at the catalyst surface and favours skeletal isomerisation [24]. In the present study, the highest $\mathrm{S}_{\mathrm{LinBut}}$ values were measured for $\mathrm{WO}_{3} / \mathrm{SiO}_{2}-\mathrm{G}$ catalysts at $300{ }^{\circ} \mathrm{C}$ (Table 2) and at $200{ }^{\circ} \mathrm{C}$, it was higher for $18.5 \% \mathrm{H}_{4} \mathrm{SiW}_{12} \mathrm{O}_{40} / \mathrm{SiO}_{2}-\mathrm{G}$ than for $39.7 \% \mathrm{WO}_{3} / \mathrm{SiO}_{2}-\mathrm{G}(29.3 \%$ instead of $25.1 \%$ after 22-24 h). It suggests that strong BAS were able to activate another isomerisation route corresponding to isomerisation of isobutene but this route was minor (Figure 9). In that mind, supported $\mathrm{WO}_{3}$ and $\mathrm{H}_{4} \mathrm{SiW}_{12} \mathrm{O}_{40}$ were previously shown to isomerise butenes into isobutene [27,78]. Strong Brønsted acidity was also reported to be the key to a high isomerization rate in the reverse reaction of n-butanol to isobutene over different zeolite catalysts [8]. LAS present in both $\mathrm{H}_{4} \mathrm{SiW}_{12} \mathrm{O}_{40} / \mathrm{SiO}_{2}-\mathrm{G}$ and $\mathrm{WO}_{3} / \mathrm{SiO}_{2}-\mathrm{G}$ could at least participate to the adsorption step. A well balanced BAS/LAS ratio with proper acidity strength was proposed to improve HPAs isomerisation activity in several papers [79,80]. A monomolecular direct skeletal isomerisation route taking place on LAS through $\pi$-allyl species seems to be ruled out since it has been essentially proposed for modified aluminas which own strong LAS $[81,82]$. Conversely, LAS could be involved in transformations giving rise to $\mathrm{C} 5+$ formation and catalyst deactivation [83].

\section{Conclusions}

Different oxides $\left(\mathrm{H}_{4} \mathrm{SiW}_{12} \mathrm{O}_{40}, \mathrm{WO}_{3}, \mathrm{TiO}_{2}, \mathrm{SnO}_{2}\right)$ were supported over mesoporous $\mathrm{SiO}_{2}-\mathrm{G}$ to compare the catalytic properties of Brønsted and Lewis type catalysts in the dehydration of isobutanol to butenes, a possible alternative route to produce green olefins. These oxides were supported by impregnation or grafting methods, the latter leading to a better deposit inside the mesopores than the former. The solids obtained were well-dispersed amorphous oxide clusters of few nanometers lying over silica. It appeared that the catalytic activity was governed by the Brønsted acidity while the Lewis one has negligible contribution. $\mathrm{H}_{4} \mathrm{SiW}_{12} \mathrm{O}_{40} / \mathrm{SiO}_{2}$ which owned the highest density of BAS was the most active but the presence of strong BAS limited the selectivity to butenes to ca $80 \%$ because leading to oligomerisation and cracking side-reactions. Formation of isobutane was also indicative of hydrogen transfer occurence. $\mathrm{WO}_{3} / \mathrm{SiO}_{2}$ and $\mathrm{TiO}_{2} / \mathrm{SiO}_{2}$ which contained moderate and weak 
BAS respectively were less active but very selective to butenes $(>95 \%) . \mathrm{SnO}_{2} / \mathrm{SiO}_{2}$ which mostly contained moderate LAS and which was reduced in the reaction conditions was selective to dehydrogenation products but unselective to dehydration ones. Except for this particular system, high proportion of linear butenes (ca 30-35\%) was obtained by thermodynamic equilibrium between carbocations formed after $\mathrm{E}_{1}$ elimination. The slightly higher isomerisation activity observed for $\mathrm{H}_{4} \mathrm{SiW}_{12} \mathrm{O}_{40} / \mathrm{SiO}_{2}$ (and to a lesser extent $\mathrm{WO}_{3} / \mathrm{SiO}_{2}$ ) was attributed to strong Brønsted acid sites able to convert isobutene to linear butenes.

\section{Acknowledgments}

This work has been cofounded by INC/CNRS (Z. Buniazet $\mathrm{PhD}$ thesis grant) and IFP Energies Nouvelles. Mickael Rivallan and Emmanuel Soyer are acknowledged for acidity measurements at IFPEn and fruitful discussion.

\section{References}

[1] S. De, S. Dutta, B. Saha, Catal. Sci. Technol. 6 (2016) 7364-7385.

[2] T. Wang, M.W. Nolte, B.H. Shanks, Green Chem. 16 (2014) 548-572.

[3] B. Katryniok, S. Paul, F. Dumeignil, ACS Catal. 3 (2013) 1819-1834.

[4] M. Zhang, Y. Yu, Ind. Eng. Chem. Res. 52 (2013) 9505-9514.

[5] C. Zhao, J. A. Lercher, Angew. Chem. Int. Ed. 124 (2012) 6037-6042.

[6] B. Peng, Y. Yao, C. Zhao, J. A. Lercher, Angew. Chem. Int. Ed. 124 (2012) 2114-2117.

[7] J.D. Taylor, M.M. Jenni, M.W. Peters, Top. Catal. 53 (2010) 1224-1230.

[8] D. Zhang, S.A.I. Barri, D. Chadwick, Appl. Catal. A: Gen. 403 (2011) 1-11.

[9] D. Zhang, R. Al-Hajri, S.A.I. Barri, D. Chadwick, Chem. Commun., 46 (2010) 40884090.

[10] P.A. Jacobs, M. Tielen, J.B. Uytterhoeven, J. Catal. 50 (1977) 98-108.

[11] P. Tynjälä, T. Pakkanen, S. Mustamäki, J. Phys. Chem. B 102 (1998) 5280-5286.

[12] P. Berteau, B. Delmon, J.-L. Dallons, A. Van Gysel, Appl. Catal. 70 (1991) 307-323.

[13] C.D. Baertsch, K.T. Komala, Y.-H. Chua, E. Iglesia, J. Catal. 205 (2002) 44-57.

[14] M. Lu, G. Xiong, H. Zhao, W. Cui, J. Gu, H. Bauser, Catal.Today 25 (1995) 339-344.

[15] B. Shi, B.H. Davis, J. Catal. 157 (1995) 359-367.

[16] P. Berteau, B. Delmon, Catal. Today 5 (1989) 121-137.

[17] J.E. Herrera, J.H. Kwak, J.Z. Hu, Y. Wang, C.H.F. Peden, J. Macht, E. Iglesia, J. Catal 239 (2006) 200-211.

[18] J. Macht, E. Iglesia, Phys. Chem. Chem. Phys. 10 (2008) 5331-5343.

[19] J. Macht. C.D. Baertsch, M. May-Lozano, S.L. Soled, Y. Wang, E. Iglesia, J. Catal. 227 (2004) 479-491.

[20] M.A. Makarova, C. Williams, V.N. Romannikov, K.I. Zamaraev, J.M. Thomas, J. Chem. Soc. Faraday Trans. 86 (1990) 581-584. 
[21] E. Hong, H.-I. Sim, C.-H. Shin, Chem. Eng. J. 292 (2016) 156-162.

[22] M. Kang, J.F. DeWilde, A. Bhan, ACS Catal. 5 (2015) 602-612.

[23] A.G. Stepanov, K.I. Zamaraev, Catal. Lett. 19 (1993) 153-158.

[24] N.S. Kotsarenko, L.V. Malysheva, Kinetika i Kataliz 24 (1983) 877.

[25] M. Boll, T. Föllinger, Patent EP 2583957.

[26] C. Adam, D. Minoux, N. Nesterenko, S. Van Donk, J.-P. Dath, Patent US20130204057 A1.

[27] J. Zhang, R. Ohnishi, Y. Kamiya, T. Okuhara, J. Catal. 254 (2008) 263-271.

[28] J. Macht, R.T. Carr, E. Iglesia, J. Am. Chem. Soc. 131 (2009) 6554-6565.

[29] M. Hino, K. Arata, Green Chem. 3 (2001) 170-172.

[30] S. Roy Partington, WO2011104494 A1

[31] W. Alharbi, E. Brown, E.F. Kozhevnikova, I.V. Kozhevnikov, J. Catal. 319 (2014) 174181.

[32] A.M. Alsalme, P.V. Wiper, Y.Z. Khimyak, E.F. Kozhevnikova, I.V. Kozhevnikov, J. Catal. 276 (2010) 181-189.

[33] G.C. Bond, S.J. Frodsham, P. Jubb, E.F. Kozhevnikova, I.V. Kozhevnikov, J. Catal. 293 (2012) 158-164.

[34] C.D. Baertsch, S.L. Soled, E. Iglesia, J. Phys. Chem. B 105 (2001) 1320-1330.

[35] B. K. Hodnett, J. B. Moffat, J. Catal. 91 (1985) 93-103.

[36] K. Nakajima, Y. Baba, R. Noma, M. Kitano, J.N. Kondo, S. Hayashi, M. Hara, J. Am. Chem. Soc. 133 (2011) 4224-4227.

[37] R.M. West, D.J. Braden, J.A. Dumesic, J. Catal. 262 (2009) 134-143.

[38] H. Shintaku, K. Nakajima, M. Kitano, N. Ichikuni, M. Hara, ACS Catal. 4 (2014) 11981204.

[39] K. Nakajima, R. Noma, M. Kitano, M. Hara, J. Phys. Chem. C 117 (2013) 16028-16033.

[40] Y. Wang, F. Wang, Q. Song, Q. Xin, S. Xu, J. Xu, J. Am. Chem. Soc. 135 (2013) 15061515.

[41] A. Corma, M. Renz, Chem. Commun. (2004) 550-551.

[42] C. Hammond, S. Conrad, I. Hermans, Ang. Chem. Int. Ed. 51 (2012) 11736-11739.

[43] K.Y. Lee, M. Misono (1997) Handbook of Heterogeneous Catalysis. Part A: General principles, methods and reaction engineering, vol. 1, 118-131.

[44] Z. Buniazet, J. Couble, D. Bianchi, M. Rivallan, A. Cabiac, S. Maury, S. Loridant, J. Catal. 348 (2017) 125-134.

[45] I.S. Pieta, M. Ishaq, R.P.K. Wells, J.A. Anderson, Appl. Catal. A: Gen. 390 (2010) 127134.

[46] M. Tamura, K. Shimizu, A. Satsuma, Appl. Catal. A: Gen. 433-434 (2012) 135-145.

[47] C.A. Emeis, J. Catal, 141 (1993) 347-354.

[48] M. Boulova, A. Gaskov, G. Lucazeau, Sensors \& Actuators, B 81 (2001) 99-106.

[49] M. Ladera, J. L. G. Fierro, M. Ojeda, S. Rojas, J. Catal. 312 (2014) 195-203.

[50] J. Berry, G. R. Derrick, M. Mortimer, Polyhedron, 68 (2014) 17-22.

[51] A.D. Newman, D.R. Brown, P.S. Adam, F. Lee, K. Wilson, Phys. Chem. Chem. Phys., 8 (2006) 2893-2902. 
[52] B.K. Hodnett, J.B. Moffat, J. Catal., 88 (1984) 253-263.

[53] H. Atia, U. Armbruster, A. Martin, J. Catal. 258 (2008) 71-82.

[54] M. Kwoka, L. Ottaviano, M. Passacantando, S. Santucci, G. Czempik, J. Szuber, Thin Solid Films 490 (2005) 36-42.

[55] B. Mallesham, P. Sudarsanam, G. Raju, B. M. Reddy, Green Chem. 15 (2013) 478-489. [56] M. Kwoka, L. Ottaviano, M. Passacantando,S. Santucci, J. Szuber, Appl. Surf. Sci. 252 (2006) 7730-7733.

[57] F. Bérubé, B. Nohair, F. Kleitz, S. Kaliaguine, Chem. Mater. 22 (2010) 1988-2000.

[58] U. Sirimahachai, N. Ndiege, R. Chandrasekharan, S. Wongnawa, M.A. Shannon, SolGel Sci. Technol. 60 (2010) 56-53.

[59] I.V. Kozhevnikov, S. Holmes, M.R.H. Siddiqui, Appl. Catal. A: Gen. 214 (2001) 47-58.

[60] G. Busca, Phys. Chem. Chem. Phys. 1 (1999) 723-736.

[61] G. Busca, Catal. Today 41 (1998) 191-206.

[62] M. Daturi, L. Gorenstin Appel, J. Catal. 209 (2002) 427-432.

[63] H. Launay, S. Loridant, A. Pigamo, J.-L. Dubois, J.M.M. Millet, J. Catal. 246 (2007) 390-398.

[64] A.A. Tsyganenko, V.N. Filimonov, J. Mol. Structure, 19 (1973) 579-589.

[65] K.I. Hadjiivanov, G.N. Vayssilov, Adv. Catal. 47 (2002) 307-511.

[66] N. Sergent, P. Gélin, L. Périer-Camby, H. Praliaud, G. Thomas, Phys. Chem. Chem. Phys., 4 (2002) 4802-4808.

[67] G. Ferraris, S. De Rossi, D. Gazzoli, I. Pettiti, M. Valigi, G. Magnacca, C. Morterra, Appl. Catal. A: Gen.240 (2003) 119-128.

[68] J. Zhang, M. Kanno, Y. Wang, H. Nishii, Y.-K. Miura, Yuichi Kamiya, J. Phys. Chem. C 115 (2011) 14762-14769.

[69] V. Macho, M. Králik, E. Jurecekova, J. Hudec, L. Jurecek, Appl. Catal. A: Gen. 214 (2001) 251-257.

[70] A.G. Stepanov, K.I. Zamaraev, Catal. Lett. 19 (1993) 153-158.

[71] P. Sharma, S. Vyas, A. Patel, J. Mol. Catal. A, 214 (2004) 281-286.

[72] H. Knözinger, H. Bühl, K. Kochloefl, J. Catal. 24 (1972) 57-58.

[73] Y.H. Ruan, Y.F. Liu, Z.C. Liu, Chin. J. Catal., 25 (2004) 948-954.

[74] H. Zhang, S. Shao, R. Xiao, D. Shen, J. Zeng, Energy \& Fuels, 28 (2014) 52-57.

[75] A.R. Pradhan, J.F. Wu, S.J. Jong, T.C. Tsai, S.B. Liu, Appl. Catal. A: Gen. 165 (1997) 489-497.

[76] G. Wang, H. Zhang, Q. Zhu, X. Zhu, X. Li, H. Wang, C. Li, H. Shan, J. Catal. 351 (2017) 90-94.

[77] H. Wang, H. Wang, X. Li, C. Li, Appl. Surf. Sci. 407 (2017) 456-462.

[78] V.M. Benitez, C.A. Querini, N.S. Figoli, R.A. Comelli, Appl. Catal. A: Gen. 178 (1999) 205-218.

[79] N. de la Fuente, J.A. Wang, L.F. Chen, J. González, J. Salmones, J.L. Contreras, J. Navarrete, Catal. Commun. 102 (2017) 93-97.

[80] T. Lopez, R. Gomez, J. G. Hernandez, E. Lopez-Salinas, X. Bokhimi, A. Morales, J. L. Boldu, E. Munoz, and O. Novaro, Langmuir 15 (1999) 5820-5824. 
[81] Z.X. Cheng, V. Ponec, Appl. Catal. A: General 118 (1994) 127-138.

[82] Z.X. Cheng, V. Ponec, J. Catal. 148 (1994) 607-616.

[83] M. Trombetta, G. Busca, S. A. Rossini, V. Piccoli, U. Cornaroy, J. Catal. 168 (1997) 334-348. 


\section{Table 1}

Compositions and textural properties of supported oxide compounds and $\mathrm{SiO}_{2}$ support.

\begin{tabular}{|c|c|c|c|c|c|c|}
\hline & $\begin{array}{c}\text { ICP } \\
\text { M weight } \\
\text { percent }(\%)^{\mathrm{a}}\end{array}$ & $\begin{array}{c}\mathrm{ICP} \\
\mathrm{MO} / \mathrm{SiO}_{2} \\
(\mathrm{~mol} / \mathrm{mol})^{\mathrm{b}}\end{array}$ & $\begin{array}{c}\mathrm{S}_{\mathrm{BET}} \\
\left(\mathrm{m}^{2} \cdot \mathrm{g}^{-1}\right)\end{array}$ & $\begin{array}{c}\text { Surface } \\
\text { density } \\
(\text { at MO.nm²) }\end{array}$ & $\begin{array}{c}\mathrm{D}_{\text {pores }} \\
(\mathrm{nm})\end{array}$ & $\begin{array}{c}\mathrm{V}_{\text {pores }} \\
3^{-1} \\
\left(\mathrm{~cm}^{-1} \cdot \mathrm{g}^{2}\right)\end{array}$ \\
\hline $\mathrm{SiO}_{2}-\mathrm{G}$ & - & - & 557 & - & 5.5 & 0.85 \\
\hline $11.7 \% \mathrm{SnO}_{2} / \mathrm{SiO}_{2}-\mathrm{G}$ & 9.2 & 0.05 & 411 & 1.1 & 5.2 & 0.65 \\
\hline $26.0 \% \mathrm{SnO}_{2} / \mathrm{SiO}_{2}-\mathrm{G}$ & 20.5 & 0.14 & 351 & 3.0 & 4.7 & 0.44 \\
\hline $14.2 \% \mathrm{TiO}_{2} / \mathrm{SiO}_{2}-\mathrm{G}$ & 8.5 & 0.12 & 387 & 2.8 & 5.4 & 0.62 \\
\hline $20.4 \% \mathrm{TiO}_{2} / \mathrm{SiO}_{2}-\mathrm{G}$ & 12.2 & 0.19 & 381 & 4.0 & 4.8 & 0.52 \\
\hline $15.9 \% \mathrm{WO}_{3} / \mathrm{SiO}_{2}-\mathrm{G}$ & 12.6 & 0.05 & 409 & 1.0 & 5.4 & 0.66 \\
\hline $39.7 \% \mathrm{WO}_{3} / \mathrm{SiO}_{2}-\mathrm{G}$ & 31.5 & 0.17 & 330 & 3.1 & 5.5 & 0.51 \\
\hline $8.6 \% \mathrm{H}_{4} \mathrm{SiW}_{12} \mathrm{O}_{40} / \mathrm{SiO}_{2}-\mathrm{G}$ & 6.6 & 0.02 & 534 & 0.03 & 5.3 & 0.63 \\
\hline $18.5 \% \mathrm{H}_{4} \mathrm{SiW}_{12} \mathrm{O}_{40} / \mathrm{SiO}_{2}-\mathrm{G}$ & 14.2 & 0.06 & 375 & 0.10 & 5.5 & 0.64 \\
\hline
\end{tabular}

a: 'M' corresponds to $\mathrm{Sn}$, Ti or W metal.

': 'MO' corresponds to the supported metal oxide phase. The surface density is expressed in atoms of metal oxide phase per surface unit. 


\section{Table 2}

Conversions, selectivity values obtained for $\mathrm{SiO}_{2}-\mathrm{G}$ support and different $\mathrm{SiO}_{2}-\mathrm{G}$ supported oxides. Temperature: $300{ }^{\circ} \mathrm{C}, 1 / \mathrm{WHSV}$ : $0.33 \mathrm{~h}$, Time on stream: 4 or $20 \mathrm{~h}$.

\begin{tabular}{|c|c|c|c|c|c|c|c|c|c|c|c|c|}
\hline \multirow[t]{2}{*}{ Catalyst } & \multicolumn{2}{|c|}{ Conversion $(\%)$} & \multicolumn{2}{|c|}{$\mathrm{S}_{\text {butenes }}(\%)$} & \multicolumn{2}{|c|}{$\mathrm{S}_{\text {butanes }}(\%)$} & \multicolumn{2}{|c|}{$\mathrm{S}_{\mathrm{C} 5+}(\%)$} & \multicolumn{2}{|c|}{$\mathrm{S}_{\text {isobutyraldehyde }}(\%)$} & \multicolumn{2}{|c|}{$\mathrm{S}_{\text {LinBut }}(\%)$} \\
\hline & $4 \mathrm{~h}$ & $20 \mathrm{~h}$ & $4 \mathrm{~h}$ & $20 \mathrm{~h}$ & $4 \mathrm{~h}$ & $20 \mathrm{~h}$ & $4 \mathrm{~h}$ & $20 \mathrm{~h}$ & $4 \mathrm{~h}$ & $20 \mathrm{~h}$ & $4 \mathrm{~h}$ & $20 \mathrm{~h}$ \\
\hline $\mathrm{SiO}_{2}-\mathrm{G}$ & 3.7 & 3.5 & 90.0 & 89.0 & 1.6 & 1.2 & 8.8 & 8.7 & 0 & 0 & 30.0 & 31.0 \\
\hline $26.0 \% \mathrm{SnO}_{2} / \mathrm{SiO}_{2}-\mathrm{G}$ & 3.8 & 3.9 & 14.8 & 15.9 & 3.3 & 1.0 & 16.3 & 10.0 & 61.0 & 68.0 & 24.3 & 22.9 \\
\hline $20.4 \% \mathrm{TiO}_{2} / \mathrm{SiO}_{2}-\mathrm{G}$ & 89.3 & 64.8 & 97.4 & 94.0 & 0.4 & 0.3 & 1.3 & 5.1 & 0 & 0 & 33.0 & 33.5 \\
\hline $15.9 \% \mathrm{WO}_{3} / \mathrm{SiO}_{2}-\mathrm{G}$ & 100 & 94.0 & 90.5 & 98.3 & 0.3 & 0.1 & 9.4 & 2.1 & 0 & 0.1 & 35.0 & 34.4 \\
\hline $39.7 \% \mathrm{WO}_{3} / \mathrm{SiO}_{2}-\mathrm{G}$ & 100 & 99.3 & 89.5 & 98.0 & 0.3 & 0.1 & 7.9 & 1.2 & 0 & 0.1 & 37.0 & 35.5 \\
\hline
\end{tabular}




\section{FIGURES CAPTIONS}

Figure 1. XRD patterns of the different supported catalysts.

Figure 2. TEM images of (a,b) $26.0 \% \mathrm{SnO}_{2} / \mathrm{SiO}_{2}-\mathrm{G}, \quad(\mathrm{c}, \mathrm{d}) \quad 20.4 \% \mathrm{TiO}_{2} / \mathrm{SiO}_{2}-\mathrm{G}$ and (e,f) $18.5 \% \mathrm{H}_{4} \mathrm{SiW}_{12} \mathrm{O}_{40} / \mathrm{SiO}_{2}-\mathrm{G}$ compounds at different scales.

Figure 3. Comparison of the IR spectra of pre-treated (a) $26.0 \% \mathrm{SnO}_{2} / \mathrm{SiO}_{2}-\mathrm{G}$, (b) $20.4 \% \mathrm{TiO}_{2} / \mathrm{SiO}_{2}-\mathrm{G}$, (c) $15.9 \% \mathrm{WO}_{3} / \mathrm{SiO}_{2}-\mathrm{G}$, (d) $39.7 \% \mathrm{WO}_{3} / \mathrm{SiO}_{2}-\mathrm{G}$ and (e) $18.5 \% \mathrm{H}_{4} \mathrm{SiW}_{12} \mathrm{O}_{40} / \mathrm{SiO}_{2}-\mathrm{G}$ compounds recorded upon adsorption of pyridine at RT and followed by evacuation at $150{ }^{\circ} \mathrm{C}$. The background corresponded to the spectrum recorded at RT under dry air flow after pre-treatment.

Figure 4. Evolution of (a) the Lewis and (b) Brønsted acid sites densities of the different catalysts as a function of the pyridine desorption temperature.

Figure 5. Comparison of the IR spectra of pre-treated (a) $20.4 \% \mathrm{TiO}_{2} / \mathrm{SiO}_{2}-\mathrm{G}$, (b) $26.0 \% \mathrm{SnO}_{2} / \mathrm{SiO}_{2}-\mathrm{G}$, (c) $15.9 \% \mathrm{WO}_{3} / \mathrm{SiO}_{2}-\mathrm{G}$, (d) $39.7 \% \mathrm{WO}_{3} / \mathrm{SiO}_{2}-\mathrm{G}$ and (e) $18.5 \% \mathrm{H}_{4} \mathrm{SiW}_{12} \mathrm{O}_{40} / \mathrm{SiO}_{2}-\mathrm{G}$ compounds upon adsorption of small quantity of $\mathrm{CO}$ at $77 \mathrm{~K}$. The background corresponded to the spectrum recorded at $77 \mathrm{~K}$ after pre-treatment.

Figure 6: Evolution of the conversion, selectivity values and carbon balance with time on stream for $39.7 \% \mathrm{WO}_{3} / \mathrm{SiO}_{2}-\mathrm{G}$ catalyst. Feed composition: $\mathrm{iC}_{4} \mathrm{OH} /$ inert 35/65, 1/WHSV 0.35 h, temperature 200 ${ }^{\circ} \mathrm{C}$.

Figure 7. Evolution of the conversion, selectivity values and carbon balance with time on stream for $18.5 \% \mathrm{H}_{4} \mathrm{SiW}_{12} \mathrm{O}_{40} / \mathrm{SiO}_{2}-\mathrm{G}$ catalyst. Feed composition $\mathrm{iC}_{4} \mathrm{OH} /$ inert 35/65, 1/WHSV $0.35 \mathrm{~h}$, temperature $175^{\circ} \mathrm{C}$.

Figure 8. GC $\times \mathrm{GC}$ analysis of a condensate after catalytic testing of $18.5 \% \mathrm{H}_{4} \mathrm{SiW}_{12} \mathrm{O}_{40} / \mathrm{SiO}_{2}-\mathrm{G}$ catalyst. Feed composition 30/70, Temperature $175^{\circ} \mathrm{C}$, 1/WHSV $0.35 \mathrm{~h}$, Time on stream 24 h.

Figure 9. Proposed reaction scheme in the conversion of isobutanol to butenes. Full lines: main routes, Dashed line: minor route. 


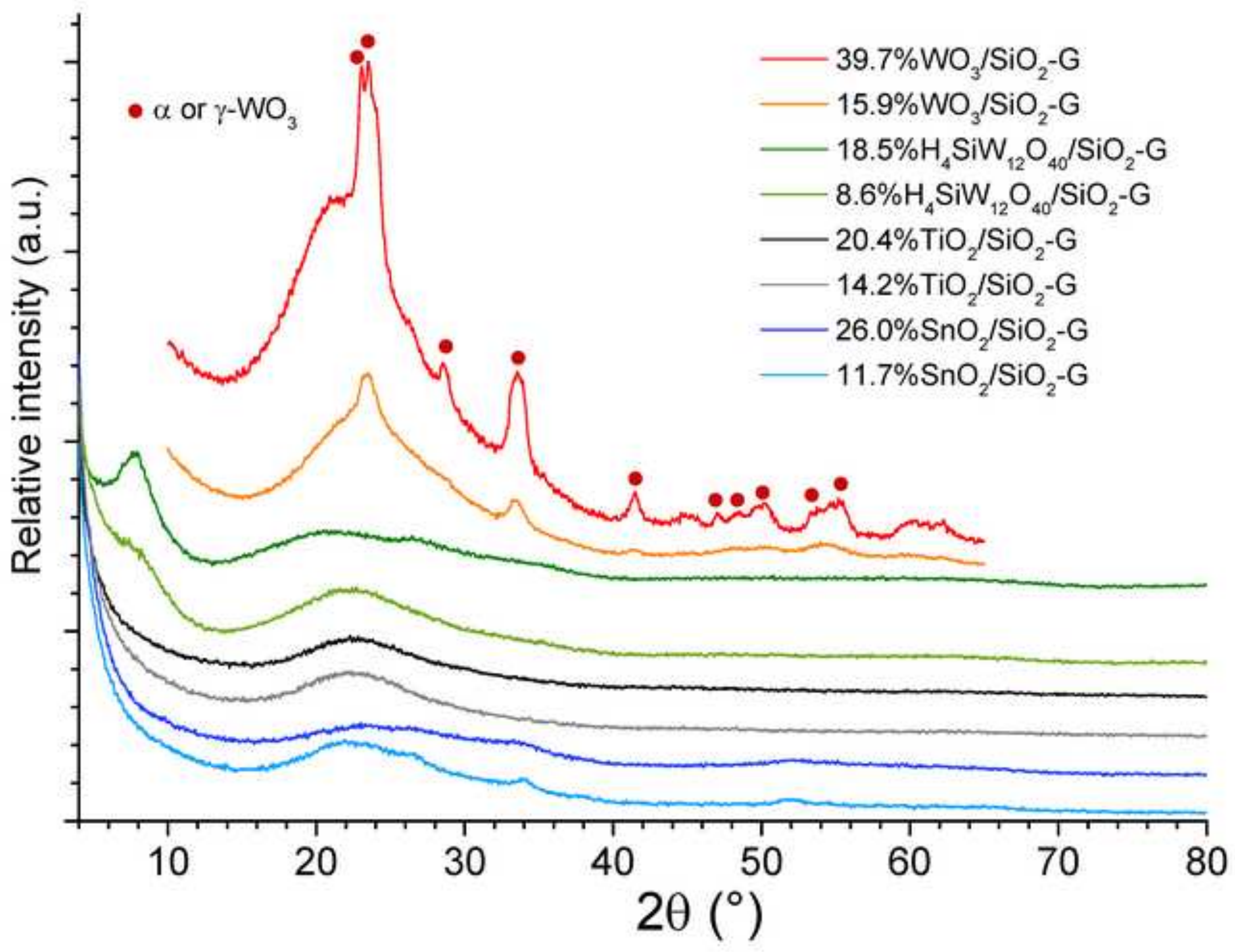




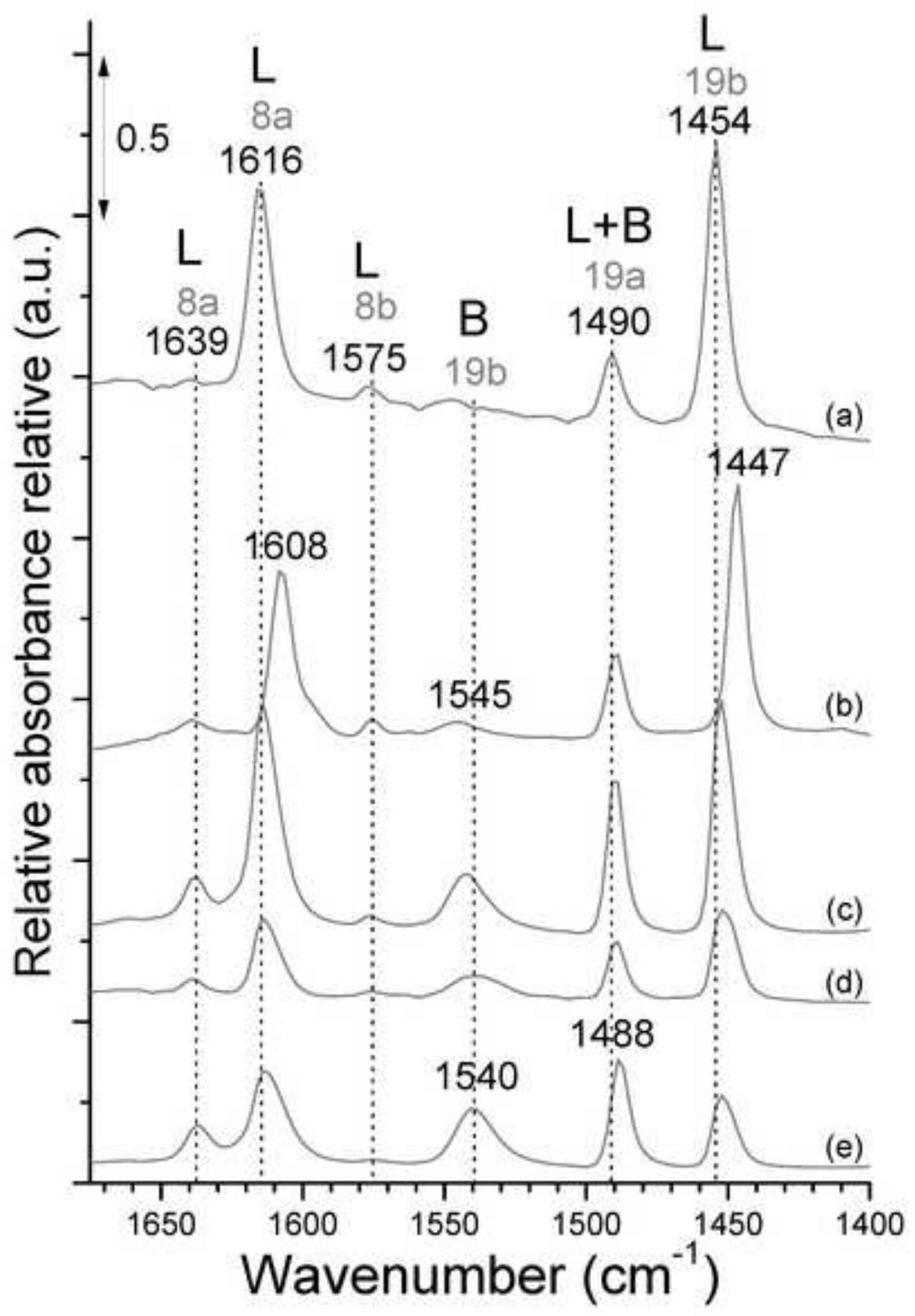



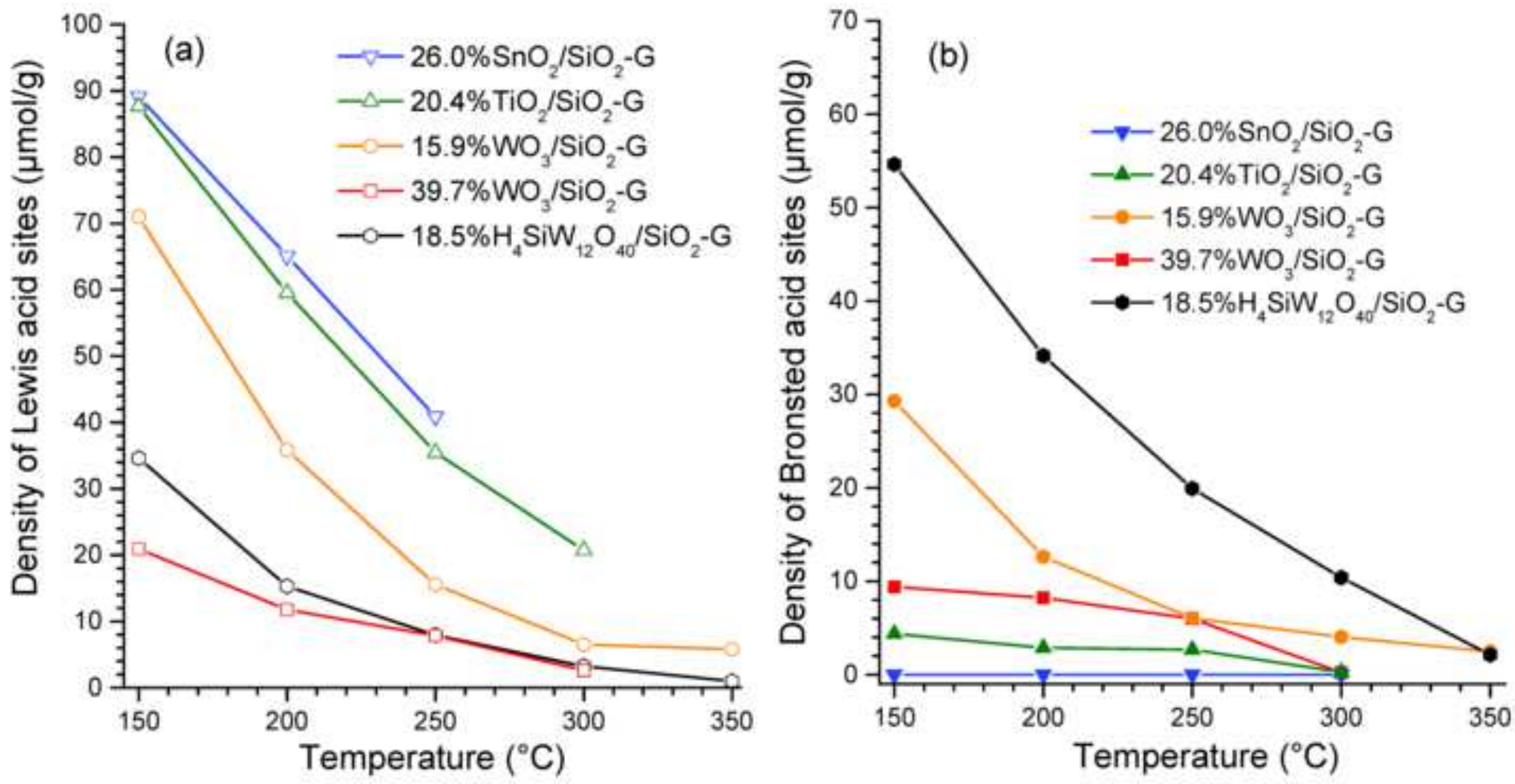


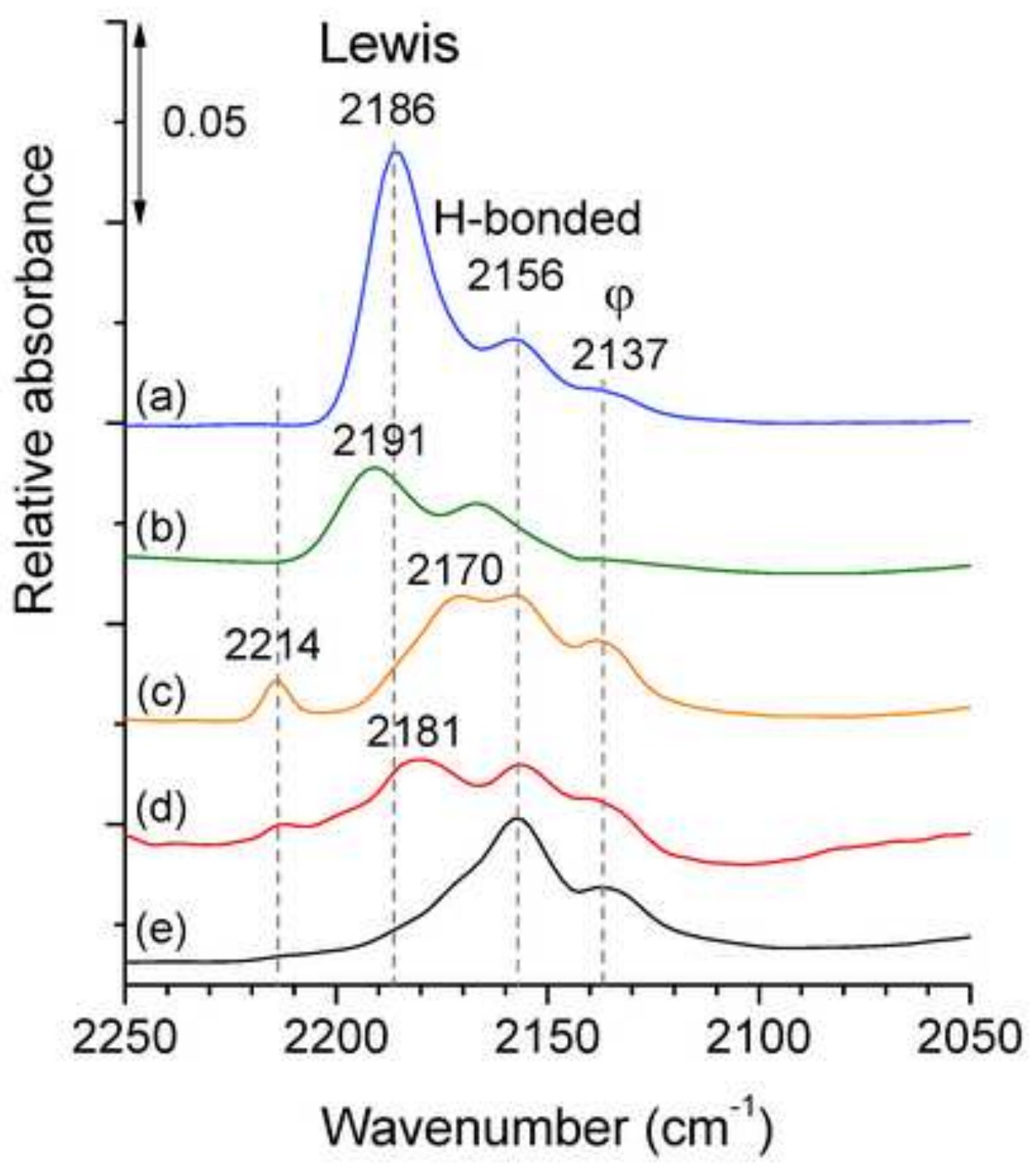




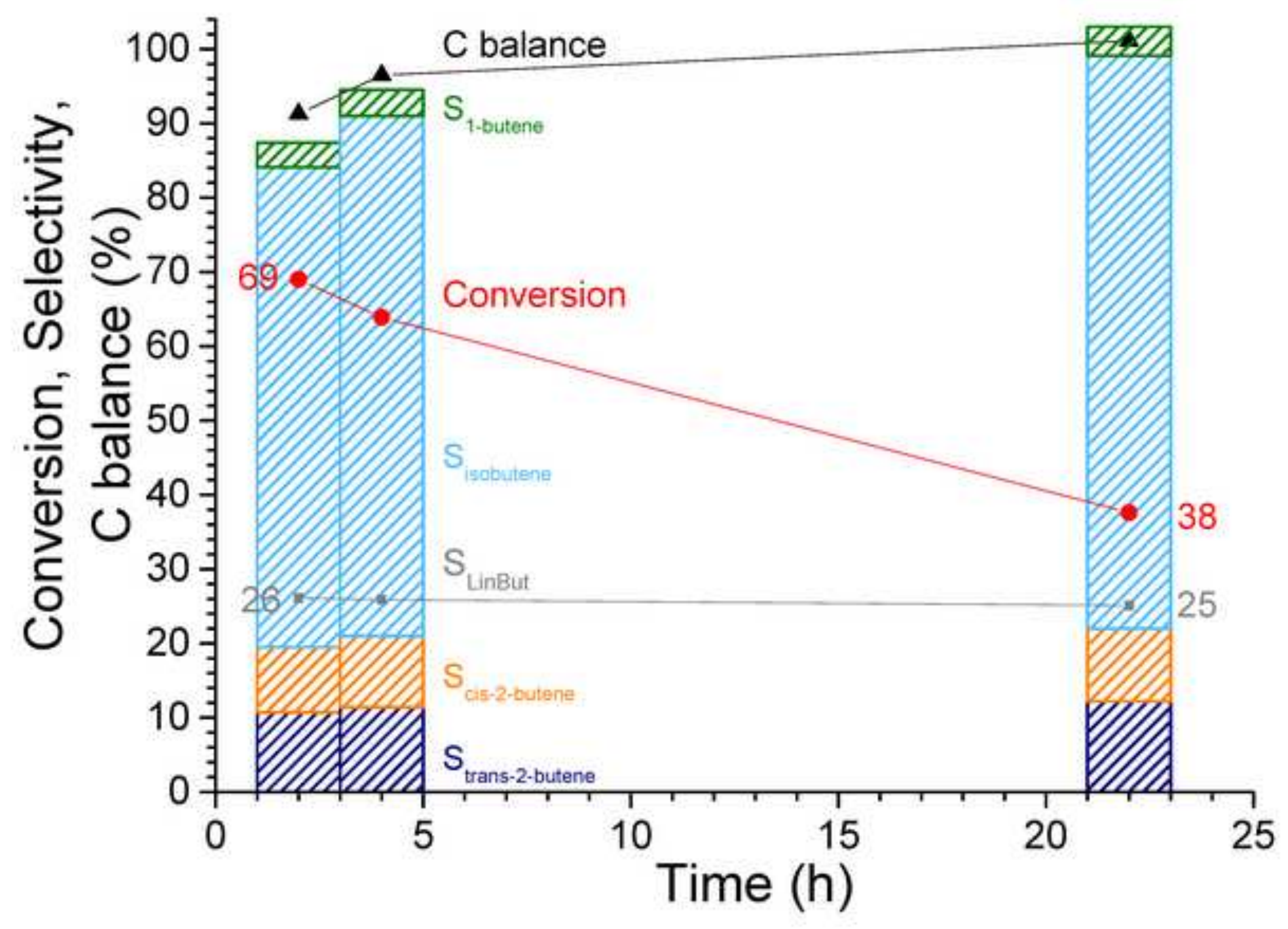




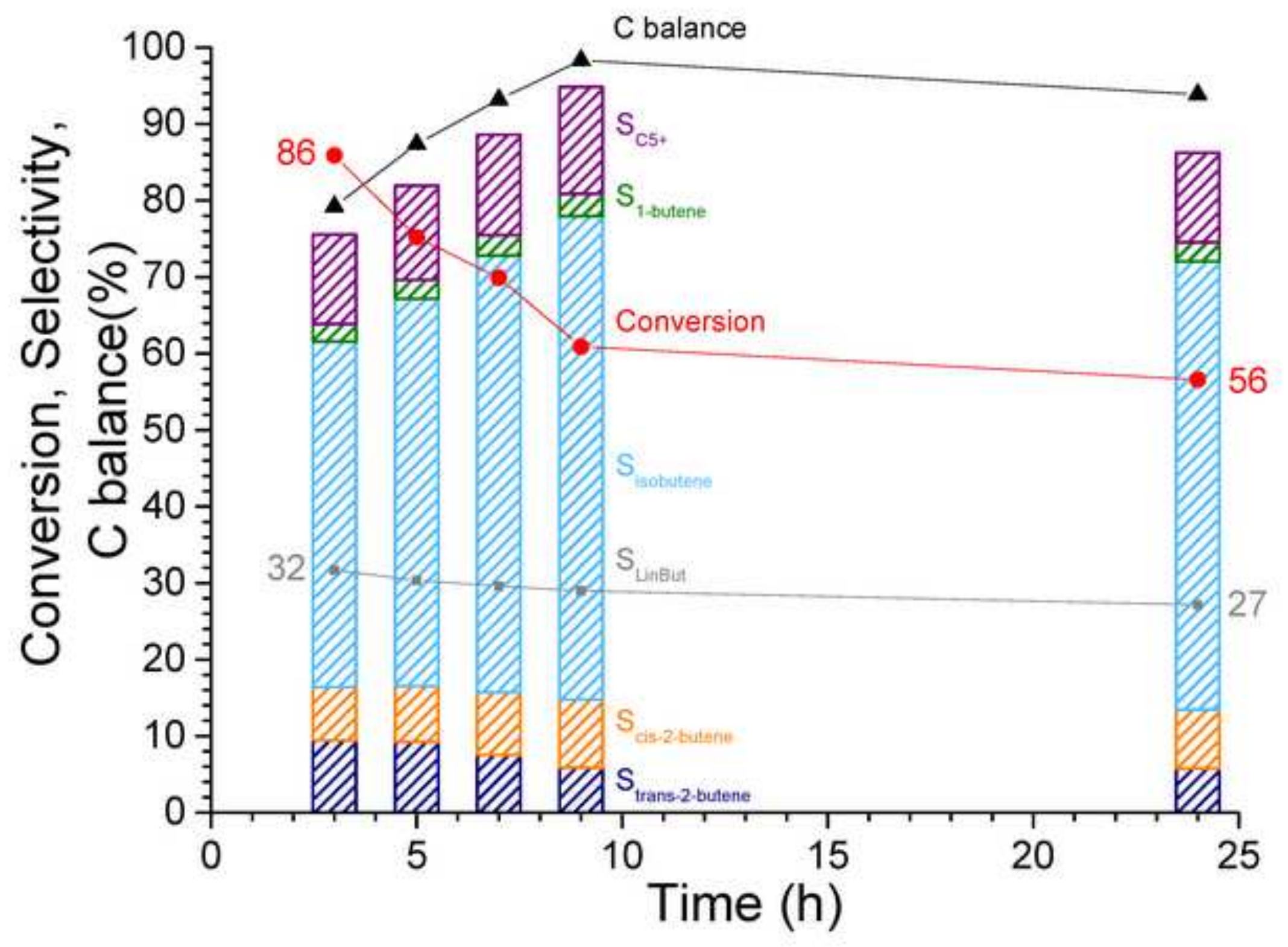




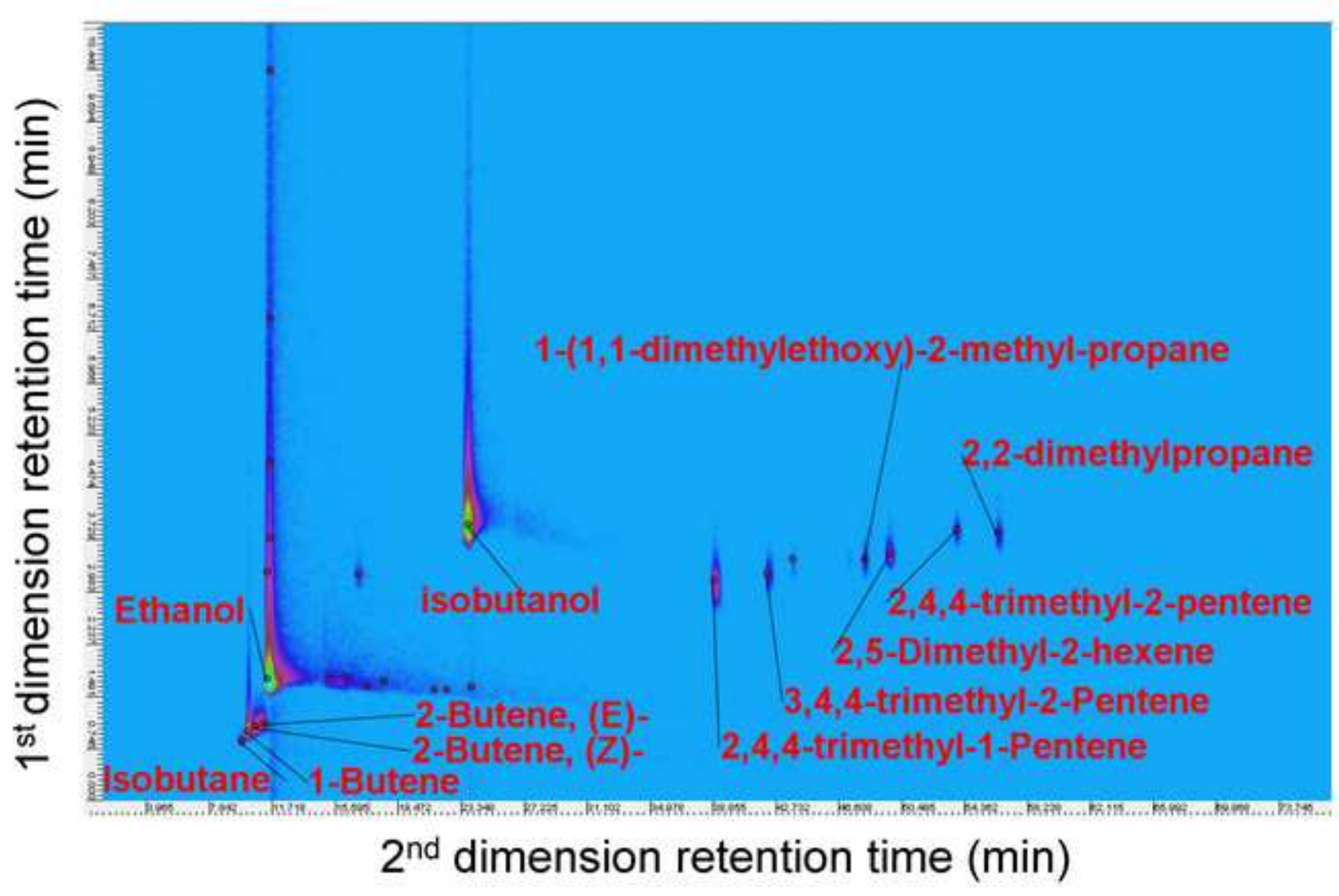


Click here to download high resolution image

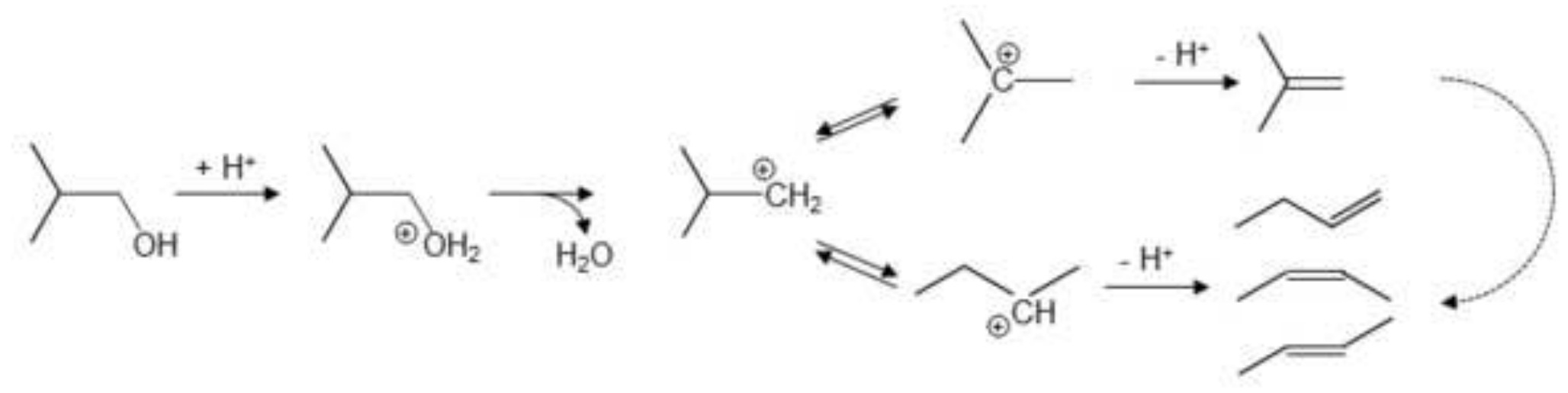




\title{
Supported oxides in the dehydration of isobutanol to butenes: relationships between acidic and catalytic properties
}

\author{
Z. Buniazet ${ }^{1,2}$ A. Cabiac, ${ }^{2}$ S. Maury, ${ }^{2}$ S. Loridant ${ }^{1, *}$ \\ ${ }^{1}$ Institut de Recherches sur la Catalyse et l'Environnement de Lyon, IRCELYON, CNRS- \\ Université Claude Bernard Lyon 1, 2 av. Einstein, F-69626 Villeurbanne Cedex, France \\ ${ }^{2}$ IFP Energies nouvelles, Rond-point de l'échangeur de Solaize, BP 3, F-69360 Solaize, \\ France
}

* Corresponding Author: Ph. + 33 [0] 472445 334, Fax + 33 [0] 472445 399, E-mail stephane.loridant@ircelyon.univ-lyon1.fr 
Table S1. XPS Binding Energies of the Si $2 p$, Sn $3 d_{5 / 2}$, Ti 2 $p_{3 / 2}$ and $\mathrm{O} 1 \mathrm{~s}$ bands observed for different compounds.

\begin{tabular}{|c|c|c|c|c|c|c|}
\hline \multicolumn{6}{|c|}{ Binding Energy $(\mathrm{eV})$} & \multirow{2}{*}{$\begin{array}{l}\text { ICP } \\
\mathrm{M} / \mathrm{Si}\end{array}$} \\
\hline Catalyst & Si $2 p$ & $\operatorname{Sn} 3 d_{5 / 2}$ & $\mathrm{Ti} 2 \mathrm{p}_{3 / 2}$ & $\mathrm{O} 1 \mathrm{~s}$ & $\mathrm{M} / \mathrm{Si}$ & \\
\hline \multirow[t]{2}{*}{$26.0 \% \mathrm{SnO}_{2} / \mathrm{SiO}_{2}-\mathrm{G}$} & 103.3 & 487.3 & - & $532.6(79 \%)$ & 0.49 & 0.14 \\
\hline & & & & $530.8(21 \%)$ & & \\
\hline \multirow[t]{2}{*}{$20.4 \% \mathrm{TiO}_{2} / \mathrm{SiO}_{2}-\mathrm{G}$} & 103.3 & - & 459.0 & $532.6(? ? \%)$ & 0.15 & 0.19 \\
\hline & & & & $530 . ?(? ? \%)$ & & \\
\hline $\mathrm{TiO}_{2}-\mathrm{P} 25$ & - & - & 458.5 & 529.7 & - & - \\
\hline $\mathrm{SiO}_{2}$ & 103.5 & - & - & 532.6 & - & - \\
\hline
\end{tabular}


Supporting Information

Table S2. Shift of the $v(\mathrm{C} \equiv \mathrm{O})$ band of CO molecules coordinated to Lewis sites compared to physisorbed CO molecules $\left(2136 \mathrm{~cm}^{-1}\right)$ and shift of the $\mathrm{v}(\mathrm{O}-\mathrm{H})$ bands located at $3720-3740 \mathrm{~cm}^{-1}$.

\begin{tabular}{ccc}
\hline Compound & $\begin{array}{c}\text { Shift of the } v(\mathrm{C} \equiv \mathrm{O}) \text { band } \\
\left(\mathrm{cm}^{-1}\right)\end{array}$ & $\begin{array}{c}\text { Shift of the } v(\mathrm{O}-\mathrm{H}) \text { bands } \\
\left(\mathrm{cm}^{-1}\right)\end{array}$ \\
\hline $26.0 \% \mathrm{SnO}_{2} / \mathrm{SiO}_{2}-\mathrm{G}$ & +51 & -100 \\
$20.4 \% \mathrm{TiO}_{2} / \mathrm{SiO}_{2}-\mathrm{G}$ & $+51 ;+42$ & -102 \\
$15.9 \% \mathrm{WO}_{3} / \mathrm{SiO}_{2}-\mathrm{G}$ & $+77 ;+45 ;+33$ & -90 \\
$39.7 \% \mathrm{WO}_{3} / \mathrm{SiO}_{2}-\mathrm{G}$ & $+72 ;+44$ & - \\
$18.5 \% \mathrm{H}_{4} \mathrm{SiW}_{12} \mathrm{O}_{40} / \mathrm{SiO}_{2}-\mathrm{G}$ & +45 & -100 \\
\hline
\end{tabular}




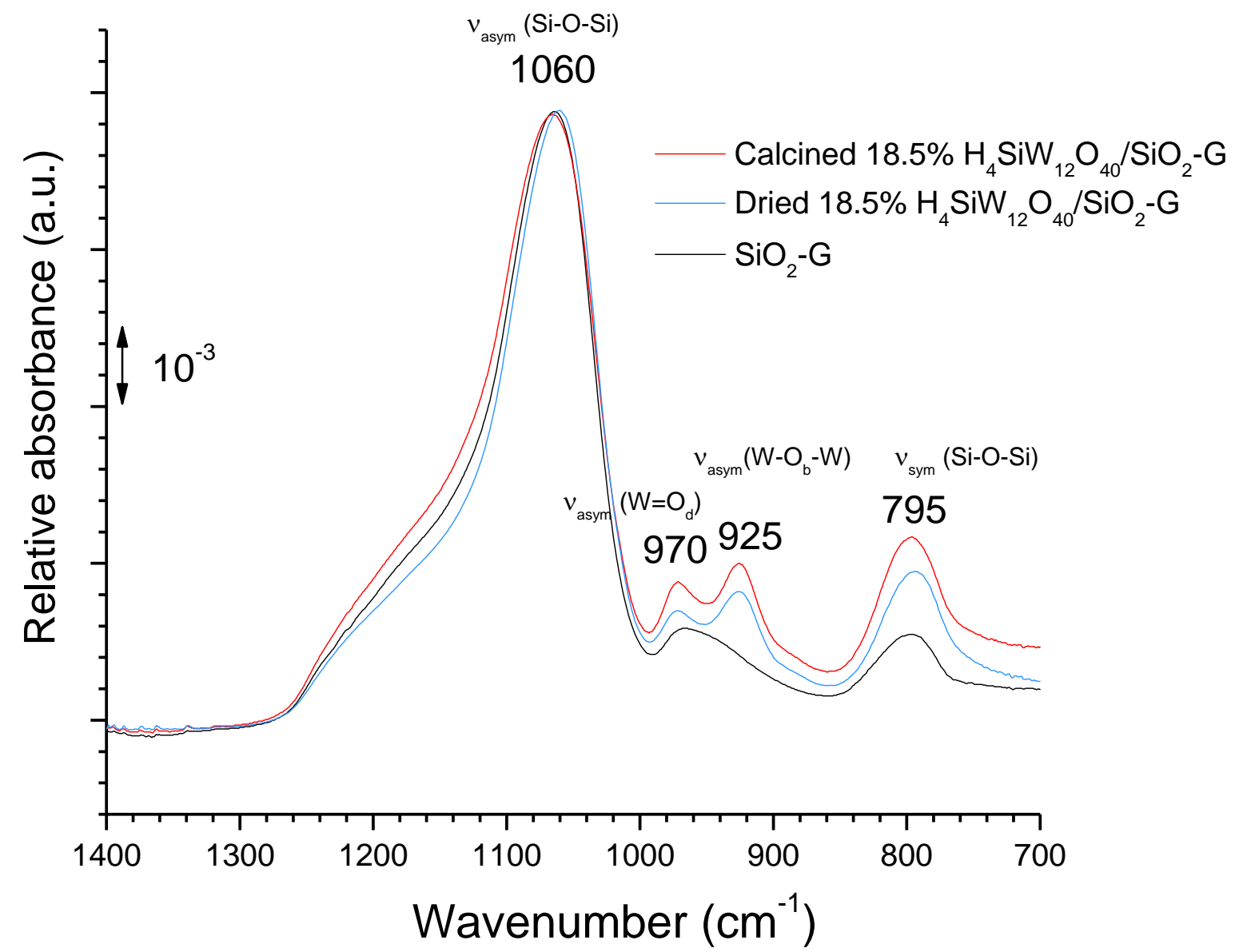

Figure S1. ATR IR spectra of the $\mathrm{SiO}_{2}-\mathrm{G}$ support, dried and calcined $18.5 \% \mathrm{H}_{4} \mathrm{SiW}_{12} \mathrm{O}_{40} / \mathrm{SiO}_{2}-\mathrm{G}$ solids. The vibrational bands of $\mathrm{SiO}_{2}$ and $\mathrm{H}_{4} \mathrm{SiW}_{12} \mathrm{O}_{40}$ were attributed from [42-44]. 
Supporting Information

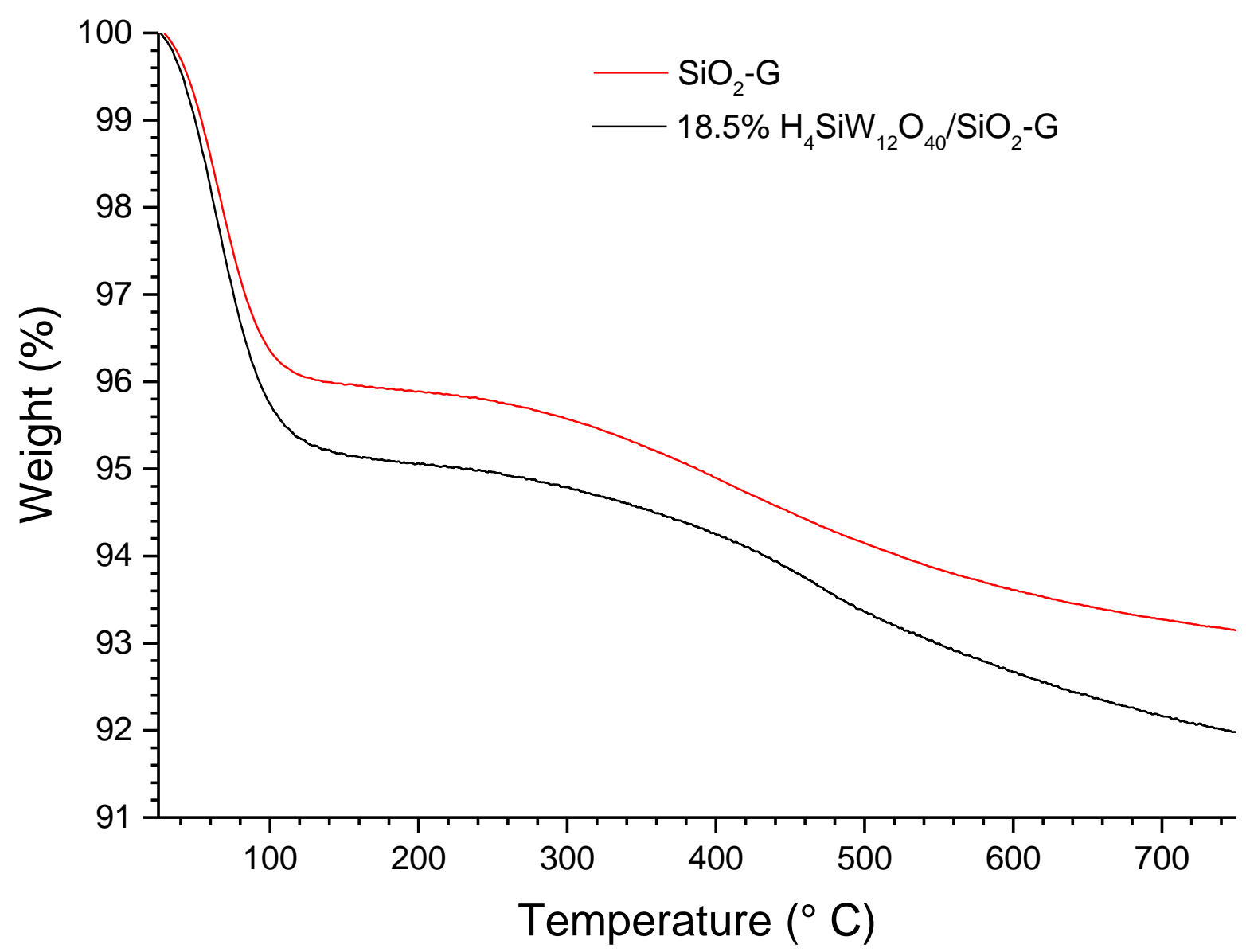

Figure S2. TGA curves of the $\mathrm{SiO}_{2}-\mathrm{G}$ support and $18.5 \% \mathrm{H}_{4} \mathrm{SiW}_{12} \mathrm{O}_{40} / \mathrm{SiO}_{2}-\mathrm{G}$ compound. 

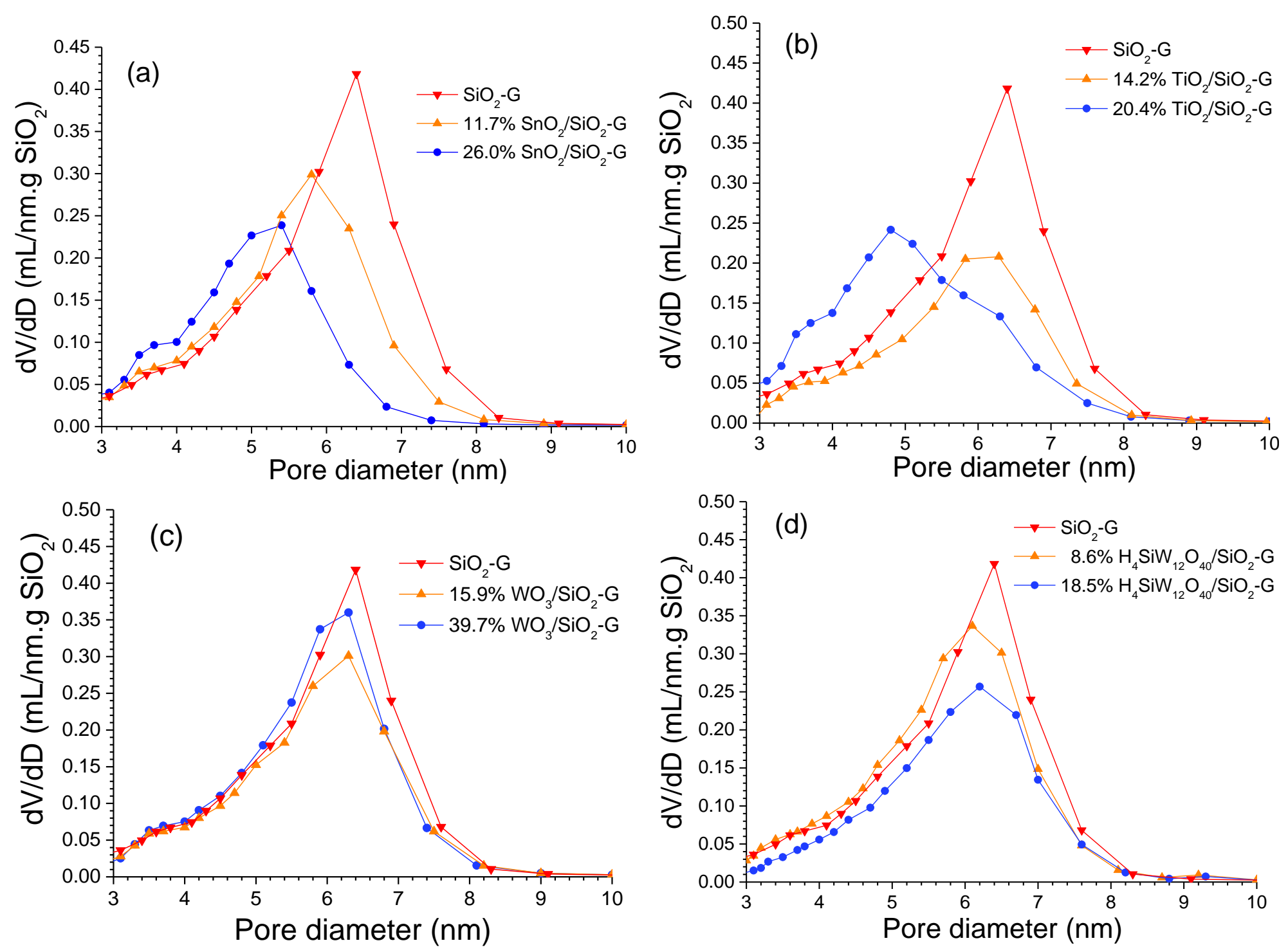

Figure S3. Pore diameter distributions of (a) $\mathrm{SnO}_{2} / \mathrm{SiO}_{2}-\mathrm{G}$, (b) $\mathrm{TiO}_{2} / \mathrm{SiO}_{2}-\mathrm{G}$, (c) $\mathrm{WO}_{3} / \mathrm{SiO}_{2}-\mathrm{G}$ and (d) $\mathrm{H}_{4} \mathrm{SiW}_{12} \mathrm{O}_{40} / \mathrm{SiO}_{2}-\mathrm{G}_{\text {compounds. }}$ 
Supporting Information 
Supporting Information

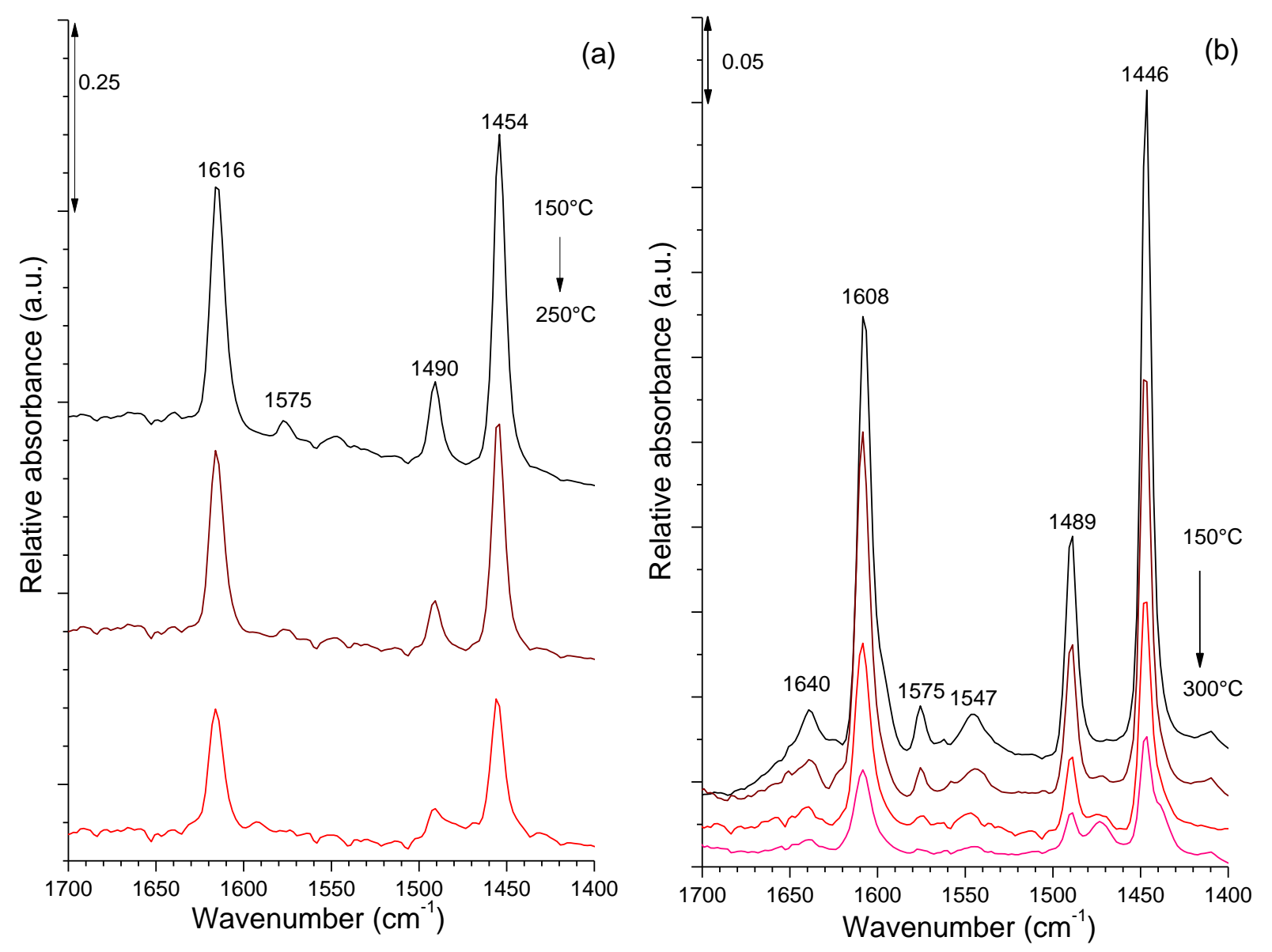

Figure S4. (a) Evolution of the IR spectrum of pretreated (a) $26.0 \% \mathrm{TiO}_{2} / \mathrm{SiO}_{2}-\mathrm{G}$, (b) $20.4 \% \mathrm{TiO}_{2} / \mathrm{SiO}_{2}-\mathrm{G}$ compounds recorded upon adsorption of pyridine at RT and followed by evacuation at increasing temperatures. The background corresponded to the spectrum recorded at RT under dry air flow after pretreatment. 

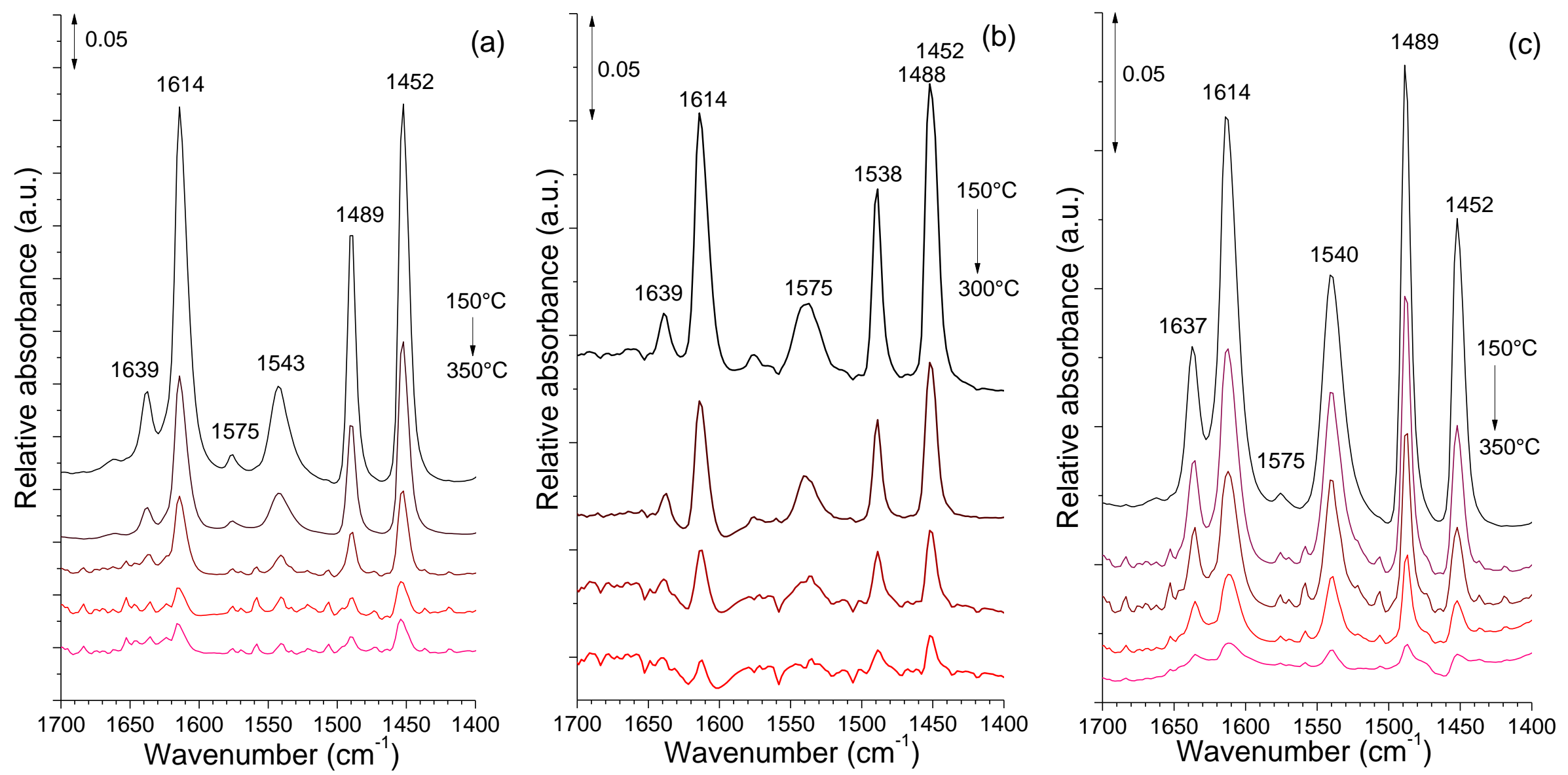

Figure S5. (a) Evolution of the IR spectrum of pretreated (a) $15.9 \% \mathrm{WO}_{3} / \mathrm{SiO}_{2}-\mathrm{G}$, (b) $39.7 \% \mathrm{WO}_{3} / \mathrm{SiO}_{2}-\mathrm{G}$ and (c) $18.5 \% \mathrm{H}_{4} \mathrm{SiW}_{12} \mathrm{O}_{40} / \mathrm{SiO}_{2}-\mathrm{G}$ compounds recorded upon adsorption of pyridine at RT and followed by evacuation at increasing temperatures. The background corresponded to the spectrum recorded at RT under dry air flow after pretreatment. 
Supporting Information
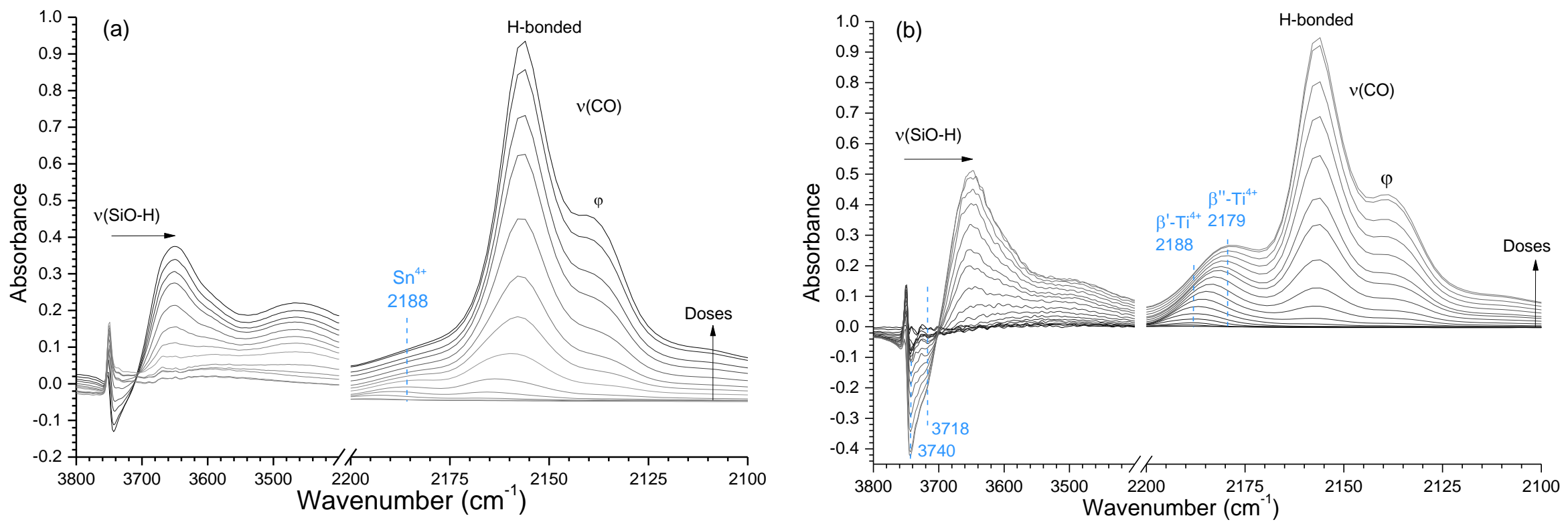

Figure S6. Evolution of the IR spectrum of pretreated (a) $26.0 \% \mathrm{SnO}_{2} / \mathrm{SiO}_{2}-\mathrm{G}$, (b) $20.4 \% \mathrm{TiO}_{2} / \mathrm{SiO}_{2}-\mathrm{G}$ compounds upon adsorption of increasing doses of $\mathrm{CO}$ at $77 \mathrm{~K}$. The background corresponded to the spectrum recorded at $77 \mathrm{~K}$ after pretreatment. 
Supporting Information
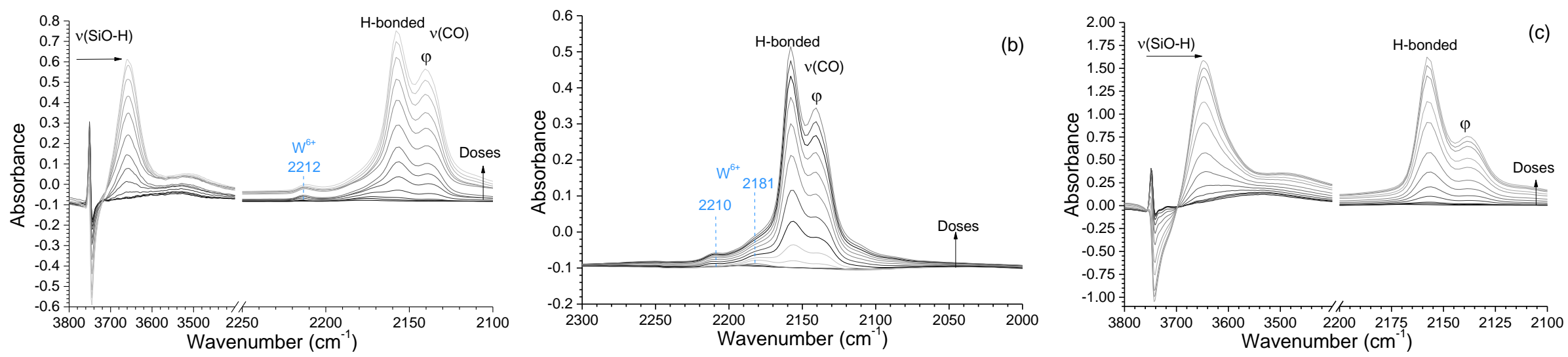

Figure S7. Evolution of the IR spectrum of pretreated (a) $15.9 \% \mathrm{WO}_{3} / \mathrm{SiO}_{2}-\mathrm{G}$, (b) $39.7 \% \mathrm{WO}_{3} / \mathrm{SiO}_{2}-\mathrm{G}$ and (c) $18.5 \% \mathrm{H}_{4} \mathrm{SiW} 12 \mathrm{O}_{40} / \mathrm{SiO}_{2}-\mathrm{G}$ compounds upon adsorption of increasing doses of $\mathrm{CO}$ at $77 \mathrm{~K}$. The background corresponded to the spectrum recorded at $77 \mathrm{~K}$ after pretreatment. 

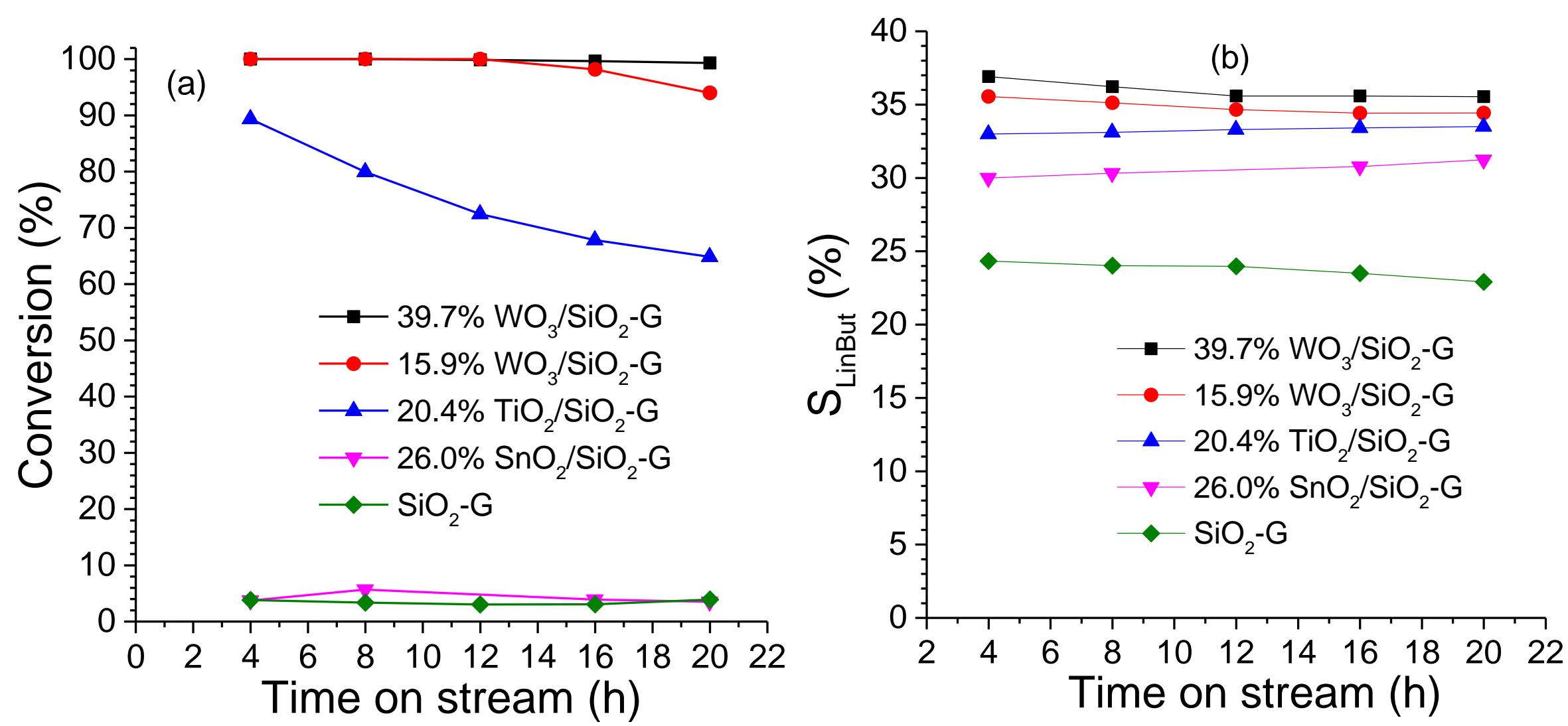

Figure S8. Evolutions of (a) the conversion and (b) the $S_{\text {LinBut }}$ value with the time on stream for the different screened catalysts. 


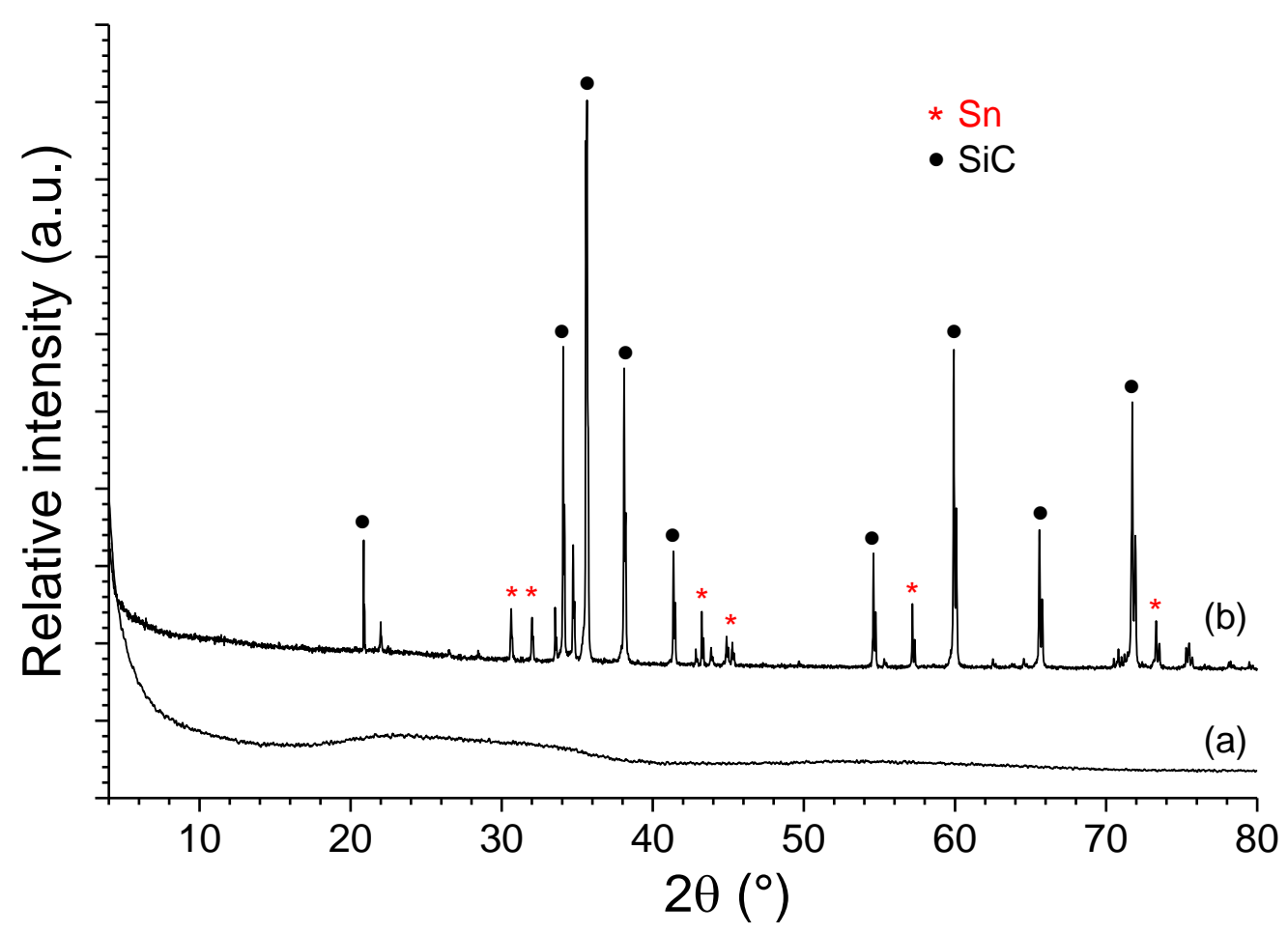

Figure S9: XRD pattern of $26.0 \% \mathrm{SnO}_{2} / \mathrm{SiO}_{2}-\mathrm{G}$ (a) before and (b) after $20 \mathrm{~h}$ of catalytic testing at $300{ }^{\circ} \mathrm{C}, 1 / \mathrm{WHSV} 0.33 \mathrm{~h}$. *: Sn tetragonal structure (ICDD: 01-089-2761), •: SiC hexagonal structure (ICDD: 04-012-5685). 


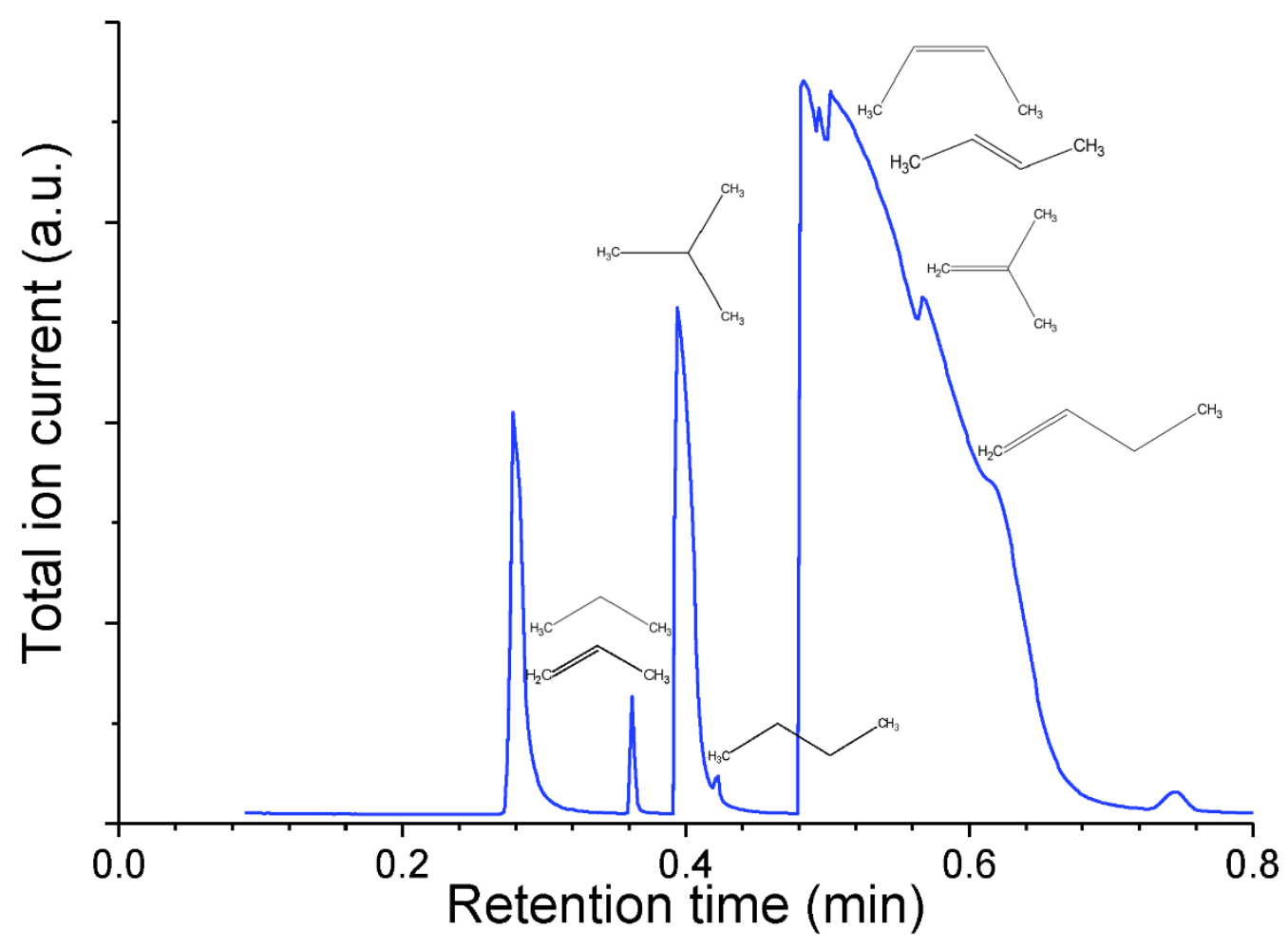

Figure S10. $\mu \mathrm{GC}-\mathrm{MS}$ analysis of gas phase during catalytic testing of $18.5 \%$ $\mathrm{H}_{4} \mathrm{SiW}_{12} \mathrm{O}_{40} / \mathrm{SiO}_{2}$-G. Feed composition $\mathrm{iC}_{4} \mathrm{OH} /$ inert $=30 / 70$, temperature $175^{\circ} \mathrm{C}, 1 / \mathrm{WHSV}$ $0.37 \mathrm{~h}$, time $24 \mathrm{~h}$. 


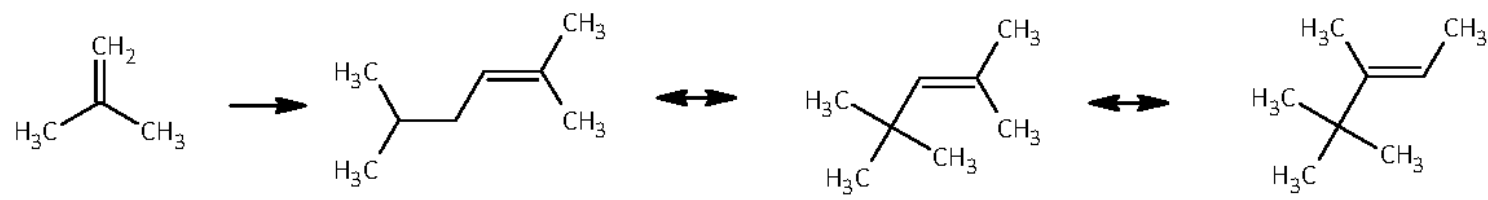<smiles>C=C(C)C</smiles><smiles>C=CCC</smiles><smiles>C/C=C\CC(C)CC</smiles><smiles>C=CC</smiles><smiles>[CH-]=CC</smiles><smiles>CCCCCCC</smiles><smiles>CCC=CCC</smiles><smiles>c1ccccc1</smiles><smiles>C=CC</smiles><smiles>CCC</smiles><smiles>C=C(C)C</smiles><smiles>CC(C)C</smiles><smiles>CC=CC</smiles><smiles>CCCC[18F]</smiles><smiles>CC(C)=CC(C)(C)C</smiles><smiles>CC(C)CC(C)(C)C</smiles><smiles>C/C=C/CC</smiles><smiles>CC(C)(C)C</smiles>

Figure S11. Formation and consecutive reaction of secondary products. 


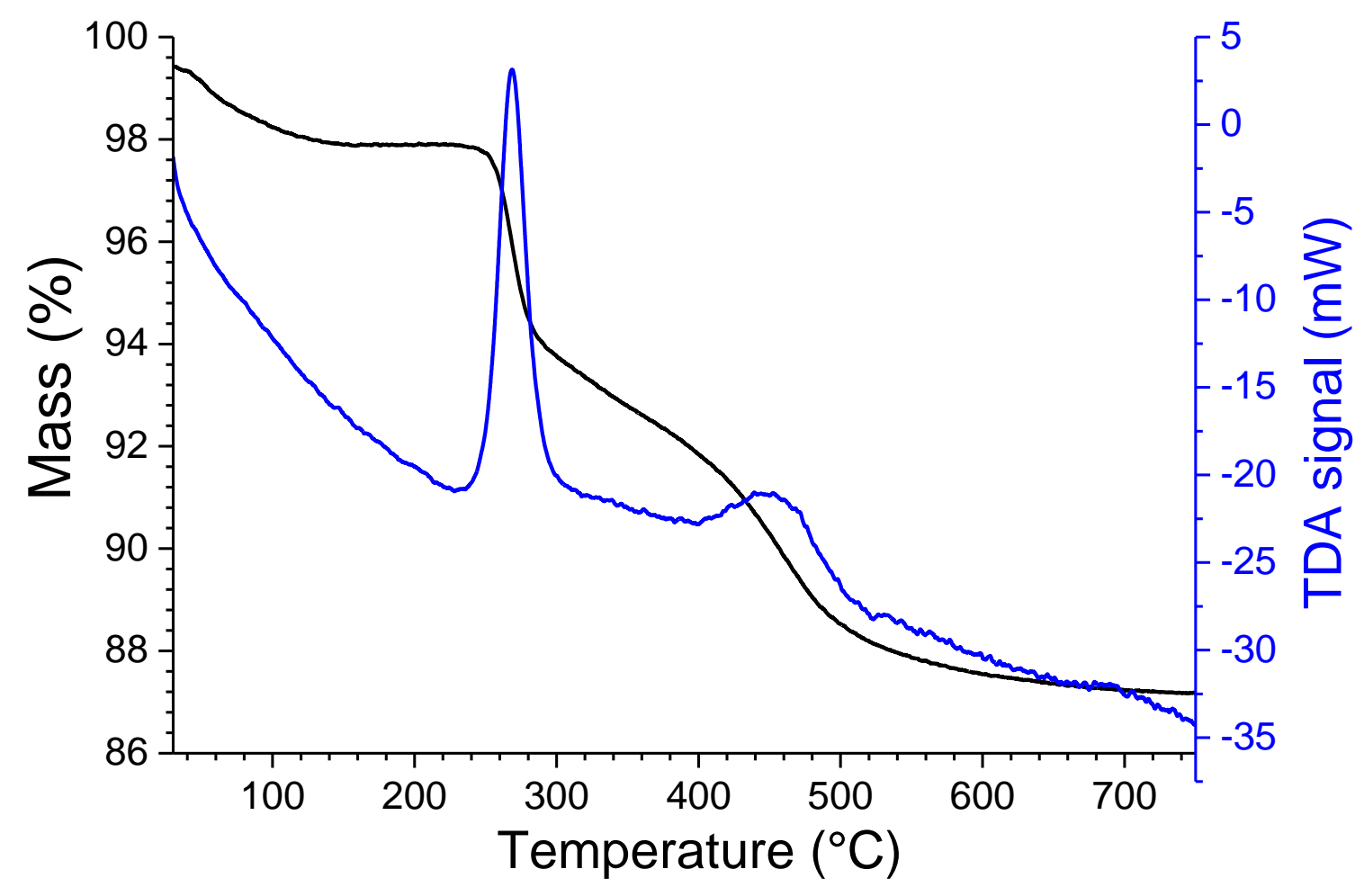

Figure S12. TGA and TDA curves obtained with $18.5 \% \mathrm{H}_{4} \mathrm{SiW}_{12} \mathrm{O}_{40} / \mathrm{SiO}_{2}-\mathrm{G}$ compound after catalytic testing. Feed composition $\mathrm{iC}_{4} \mathrm{OH} /$ inert $=30 / 70$, temperature $175^{\circ} \mathrm{C}, 1 / \mathrm{WHSV} 0.37$ $\mathrm{h}$, time $24 \mathrm{~h}$. 